\title{
Ocean carbon cycling during the past 130000 years - a pilot study on inverse palaeoclimate record modelling
}

\author{
Christoph Heinze ${ }^{1,2,3}$, Babette A. A. Hoogakker ${ }^{4}$, and Arne Winguth ${ }^{5}$ \\ ${ }^{1}$ Geophysical Institute, University of Bergen, Allégaten 70, 5007 Bergen, Norway \\ ${ }^{2}$ Uni Research Climate, Nygårdsgaten 112, 5008 Bergen, Norway \\ ${ }^{3}$ Bjerknes Centre for Climate Research, Bergen, Norway \\ ${ }^{4}$ Department of Earth Sciences, University of Oxford, South Parks Road, Oxford, OX1 3AN, UK \\ ${ }^{5}$ Department of Earth and Environmental Sciences, University of Texas Arlington, P.O. Box 19049, \\ Arlington, TX 76019, USA
}

Correspondence to: Christoph Heinze (christoph.heinze@uib.no)

Received: 14 March 2016 - Published in Clim. Past Discuss.: 18 April 2016

Revised: 5 September 2016 - Accepted: 8 September 2016 - Published: 12 October 2016

\begin{abstract}
What role did changes in marine carbon cycle processes and calcareous organisms play in glacial-interglacial variation in atmospheric $p \mathrm{CO}_{2}$ ? In order to answer this question, we explore results from an ocean biogeochemical general circulation model. We attempt to systematically reconcile model results with time-dependent sediment core data from the observations. For this purpose, we fit simulated sensitivities of oceanic tracer concentrations to changes in governing carbon cycle parameters to measured sediment core data. We assume that the time variation in the governing carbon cycle parameters follows the general pattern of the glacial-interglacial deuterium anomaly. Our analysis provides an independent estimate of a maximum mean sea surface temperature drawdown of about $5^{\circ} \mathrm{C}$ and a maximum outgassing of the land biosphere by about $430 \mathrm{PgC}$ at the Last Glacial Maximum as compared to pre-industrial times. The overall fit of modelled palaeoclimate tracers to observations, however, remains quite weak, indicating the potential of more detailed modelling studies to fully exploit the information stored in the palaeoclimatic archive. This study confirms the hypothesis that a decline in ocean temperature and a more efficient biological carbon pump in combination with changes in ocean circulation are the key factors for explaining the glacial $\mathrm{CO}_{2}$ drawdown. The analysis suggests that potential changes in the export rain ratio $\mathrm{POC}: \mathrm{CaCO}_{3}$ may not have a substantial imprint on the palaeoclimatic archive. The use of the last glacial as an inverted analogue to potential ocean acidification impacts thus may be quite limited.
\end{abstract}

A strong decrease in $\mathrm{CaCO}_{3}$ export production could potentially contribute to the glacial $\mathrm{CO}_{2}$ decline in the atmosphere, but this remains hypothetical.

\section{Introduction}

The drawdown of the atmospheric $\mathrm{CO}_{2}$ mixing ratio from 280-290 to 180 ppm has become well known since the mid1980s, following the analysis of the Antarctic ice cores (Neftel et al., 1982; Barnola et al., 1987; Siegenthaler et al., 2005). Despite a series of attempts to explain this major fluctuation in the key atmospheric greenhouse gas $\mathrm{CO}_{2}$, an overall closed explanation is still missing (Broecker and Peng, 1986; Heinze et al., 1991; Heinze and Hasselmann, 1993; Archer and Maier-Reimer, 1994; Sigman and Boyle, 2000; Archer et al., 2000; Brovkin et al., 2007). An understanding of the positive feedback between climate and atmospheric $\mathrm{CO}_{2}$ content (see Shakun et al., 2012) is also important for quantifying the changing carbon cycle today. The glacialinterglacial $\mathrm{CO}_{2}$ variations are mainly caused by a redistribution of carbon between the Earth system reservoirs - ocean, atmosphere, and land. In contrast, the modern carbon cycle is perturbed by the addition of $\mathrm{CO}_{2}$ to the Earth's surface reservoirs. This additional $\mathrm{CO}_{2}$ was previously unavailable to interact with the biogeochemical processes occurring in these reservoirs. Nevertheless, a reliable reconstruction of glacial-interglacial carbon dynamics with Earth system mod- 
els would enhance their predictability of future carbon cycle changes. The human-induced $\mathrm{CO}_{2}$ emissions from fossil-fuel burning, cement manufacturing, and land-use change have raised the atmospheric $\mathrm{CO}_{2}$ mixing ratio to $400 \mathrm{ppm}$ relative to a pre-industrial level of 278 ppm (Le Quéré et al., 2014). The atmospheric $\mathrm{CO}_{2}$ mixing ratio would be considerably higher if the ocean did not take up a part of the human-made excess $\mathrm{CO}_{2}$ from the atmosphere, primarily through physicochemical buffering (Bolin and Eriksson, 1959; Maier-Reimer and Hasselmann, 1987; Joos et al., 2013). This marine $\mathrm{CO}_{2}$ buffering has the side effect of reducing the seawater $\mathrm{pH}$ (Haugan and Drange, 1996; Caldeira and Wickett, 2003). The impact of this progressing ocean acidification on marine biota, ecosystems, and biogeochemical processes is subject to broad interdisciplinary research, and harmful effects have been identified (Raven, 2005; Gattuso and Hansson, 2011). In particular, a reduction in the formation of calcium carbonate $\left(\mathrm{CaCO}_{3}\right)$ shell material is key in ocean acidification impact research (Riebesell et al., 2007; Iglesias-Rodriguez et al., 2008). Several potential geologic analogues for ocean acidification have been suggested, including the PalaeoceneEocene Thermal Maximum at 56 Ma (Zachos et al., 2005), $\mathrm{CO}_{2}$ release from the Siberian Traps Large Igneous Province (Svensen et al., 2009), and methane release from magmatic intrusion into coal beds (Retallack, 2008). The lack of sedimentary information prior to 180 million years before present limits our knowledge about ecosystems back in deep time. Another prominent example of significant carbon fluctuations is the last glacial-interglacial cycle. For example, the lower $\mathrm{CO}_{2}$ partial pressure at the Last Glacial Maximum (LGM) around $21 \mathrm{kyr} \mathrm{BP} \mathrm{(21000} \mathrm{years} \mathrm{before} \mathrm{present)} \mathrm{could}$ be used as a reverse palaeo-analogue of a high- $\mathrm{CO}_{2}$ world. Can we say anything about the average behaviour of marine biota with respect to $\mathrm{CaCO}_{3}$ formation under glacial conditions in order to learn about possible future developments? Evidence for better preservation of foraminifera shells is provided by Barker and Elderfield (2002), which would be in line with higher glacial carbonate ion concentrations in surface waters (Yu et al., 2014).

In this study, we combine a coarse-resolution biogeochemical ocean general circulation model (BOGCM) together with long sediment core time series records in order to determine the most likely change in ocean carbon cycle parameters during the last climatic cycle. We also include the "rain ratio" $\mathrm{CaCO}_{3}: \mathrm{C}_{\text {org }}$ (carbon atoms bound to $\mathrm{CaCO}_{3}$ shell material vs. carbon atoms bound to organic carbon in biogenic particulate matter during biological production) in the analysis. This approach would allow us to assess whether the $\mathrm{CaCO}_{3}$ formation in the glacial low- $\mathrm{CO}_{2}$ world increased or not. $\mathrm{A} \mathrm{CaCO}_{3}$ production increase at the LGM would be consistent with a decrease in $\mathrm{CaCO}_{3}$ formation in a high$\mathrm{CO}_{2}$ world. The model simulates a time-dependent sediment record at each model grid point for variations in single parameters over the past $130 \mathrm{kyr}$ (see Sect. 2). We determine the resulting model sensitivities for the sediment core tracers in relation to a number of key governing parameters of the ocean carbon cycle (see Sect. 3). The sensitivities are projected onto a linear response model. This simplified model is then used for a simultaneous fit of all carbon cycle parameters to available sediment core data from the observed palaeoclimatic archive (Sect. 4). We pursue a multi-tracer approach by considering data on marine $\mathrm{CaCO}_{3}$ wt $\%$, $\mathrm{BSi}$ wt $\%$ (BSi is biogenic silica or opal; see Ragueneau et al., 2000), $\delta^{13} \mathrm{C}_{\text {planktonic }}, \delta^{13} \mathrm{C}_{\text {benthic }}$, and the atmospheric $\mathrm{CO}_{2}$ record of the Vostok ice core (Barnola et al., 1987; the EPICA Dome $\mathrm{C}$ ice core data will be used to define the sensitivity experiments which are used as input to the linear response model; see below).

\section{Model description}

Here we use the Hamburg Oceanic Carbon Cycle Model (HAMOCC; Maier-Reimer, 1993; Maier-Reimer et al., 2005) in its annually averaged version ("HAMOCC2s") in order to keep the computational effort for equilibrating the sediment coverage within feasible limits (Heinze and MaierReimer, 1999; Heinze et al., 1999; Heinze et al., 2003; Heinze et al., 2009). This biogeochemical ocean model requires three-dimensional velocity and thermohaline fields as well as ice cover data as input. For the spin-up of the model, a velocity field representing the pre-industrial conditions ("interglacial first guess"; Winguth et al., 1999) with an annually averaged circulation from the Large Scale Geostrophic dynamical ocean general circulation model (Maier-Reimer et al., 1993) is employed. The effect of deep convective mixing at high latitudes is considered in this forcing, which is used for transporting the passive tracer substances within the model water column reservoir. The model has a horizontal resolution of $3.5^{\circ} \times 3.5^{\circ}$, while the vertical resolution decreases downward with 11 layers centred at $25,75,150,250$, $450,700,1000,2000,3000,4000$, and $5000 \mathrm{~m}$. The bioturbated top sediment zone (the "sediment mixed layer") is structured into 10 layers which are separated by "downcore" interfaces at $0,0.3,0.6,1.1,1.6,2.1,3.1,4.1,5.1,7.55$, and $10 \mathrm{~cm}$. The simplifying assumption is made that no pore water reactions take place below $10 \mathrm{~cm}$ depth in the sediment (following Smith and Rabouille, 2002; Boudreau, 1997). HAMOCC2s parameterises the processes of air-sea gas exchange, biogenic particle export production out of the ocean surface layer, particle flux through the water column and particle degradation by remineralisation and re-dissolution, advection as well as mixing of dissolved substances within the ocean velocity field, deposition of particulate matter on the seafloor, pore water chemistry and diffusion, advection of solid sediment components, bioturbation, and sediment accumulation (export out of the sediment mixed layer or "burial"). The general concept of the sediment model closely follows Archer et al. (1993). 
For the present model configuration, the following tracer concentrations are used as prognostic variables: the atmosphere includes ${ }^{12} \mathrm{CO}_{2}$ (carbon dioxide), $\delta^{13} \mathrm{CO}_{2}$, and $\mathrm{O}_{2}$; the water column contains DIC (dissolved inorganic carbon), alkalinity (TAlk), POC (particulate organic carbon), DOC (dissolved organic carbon), $\mathrm{CaCO}_{3}$ (calcium carbonate or particulate inorganic carbon) of ${ }^{12} \mathrm{C}$ and ${ }^{13} \mathrm{C}$, particulate organic phosphorus (POP), dissolved $\mathrm{O}_{2}$, dissolved $\mathrm{PO}_{4}^{3-}$ as a biolimiting nutrient, silicic acid $\mathrm{Si}(\mathrm{OH})_{4}$, and opal (biogenic particulate silica $\mathrm{BSi}$ ); and sediment processes include pore waters - the same dissolved substances as in the water column - as well as solid sediment with clay, $\mathrm{CaCO}_{3}$, opal, organic carbon, and organic phosphorus.

The model has been described in detail before (Heinze et al., 1999; Heinze et al., 2003; Heinze et al., 2006). Details about the process parameterisations are summarised in Appendix A. In contrast to previous model versions, the treatment of the inorganic carbon chemistry was updated following the procedure as detailed in Dickson et al. (2007). As compared to the previously used quantifications for the reaction constants for the dissociation of carbonic and boric acid according to Mehrbach et al. (1973), the solubility product for $\mathrm{CaCO}_{3}$ after Ingle (1975), and the pressure dependencies of Edmond and Gieskes (1970), the model required only minor retuning in order to correctly predict the pre-industrial atmospheric $p \mathrm{CO}_{2}$ of ca. $280 \mu$ atm. As before, DIC and TAlk are used as "master tracers" from which the other derived inorganic carbon species such as the $\mathrm{CO}_{3}^{2-}$ concentration, the carbonate saturation, and the $\mathrm{pH}$ value are computed through a Newton-Raphson algorithm. A further extension of the model as presented in Heinze et al. (2009) is the introduction of separate fields for POP (particulate organic phosphorus), DOP (dissolved organic phosphorus), and solid organic phosphorous in the sediment mixed layer to allow for variable stoichiometry ("Redfield ratios", C:P) in this study. The other ocean water column and pore water processes are represented through parameterisations as described in earlier model versions

\subsection{Transport of age information and passive tracers in the sediment}

In addition to the various solid sediment components, the model also predicts the age of each sediment component. The age of the amount of each component rained onto the model seafloor is set to the actual model time step. The age information is then passed down into the model sediment layer as a passive tracer. This information transport is also dependent on the pore water dissolution reactions, the deposition flux, the vertical sediment advection, and the bioturbation. Each solid sediment species has its own age tracer. The higher the sediment accumulation rate is, the closer the age values of the four different sediment component ages are. For a schematic of the sediment model, see Heinze et al. (2009) (Figs. 1 and 2 therein).
The model sediment is initialised at age 0 with only clay sediment layers and then spun up. During the progressing integration, the model builds up its own biogenic sediment and clay sediment according to the dust deposition and the kinetic control of the continental inputs of nutrients, carbon, and alkalinity as prescribed through bulk numbers. Simultaneously with the sediment accumulation, the age structure of each solid weight fraction is established. In equilibrium, the global sediment accumulation rates are a function of the continental input rates. The local sediment accumulation rates and sediment compositions are fully prognostic variables. In order to also "flush" the sediment mixed layer in lowaccumulation regions of the world ocean, the model is spun up for 100000 years to achieve overall quasi-equilibrium (as documented by the stability of the atmospheric $p \mathrm{CO}_{2}$ level and the asymptotic approach of the simulated globally integrated sediment accumulation rates to the globally prescribed continental matter input fluxes).

The model includes the cycling of ${ }^{13} \mathrm{C}$. The observed foraminiferal $\mathrm{CaCO}_{3}$ sediment record reflects $\delta^{13} \mathrm{C}$ variations from both the surface and the deep waters (depending on the shell material analysis of the different surfaceand deep-dwelling species). As an extension to Heinze et al. (2009), the present model version also includes sedimentary benthic $\delta^{13} \mathrm{C}$. Normally, only the surface ocean $\delta^{13} \mathrm{C}$ $\left(\delta^{13} \mathrm{C}_{\text {planktonic }}\right)$ is included in the simulated $\mathrm{CaCO}_{3}$ deposited onto the model top sediment layer and then treated subsequently during pore water reactions and sediment advection. The reason for this is that we have no explicit benthic production of foraminifera in the model. Applying the basic concept of the passive age tracer treatment in the early diagenesis module, we also transport the $\delta^{13} \mathrm{C}_{\text {benthic }}$ signal of the $\mathrm{CaCO}_{3}$ fraction within the sediment mixed layer (where we set the benthic solid $\delta^{13} \mathrm{C}$ value for the depositing $\mathrm{CaCO}_{3}$ material to the respective bottom water $\delta^{13} \mathrm{C}$ of the model layer directly over the respective top sediment box). Thus, the following sedimentary variables are included in the present model for direct comparison with values from sediment core analysis: the "foraminiferal" values of $\delta^{13} \mathrm{C}_{\text {planktonic }}, \delta^{13} \mathrm{C}_{\text {benthic }}$ (as the latter would be recorded in reality, for example, by the foraminiferal species Cibicidoides wuellerstorf; see Zahn et al., 1986), and also their vertical difference $\Delta \delta^{13} \mathrm{C}=\delta^{13} \mathrm{C}_{\text {planktonic }}-\delta^{13} \mathrm{C}_{\text {benthic }}$ as an indicator of the strength of the biological pump (or the vertical nutrient gradient in the water column; see Shackleton and Pisias, 1985). The model master tracers DIC and TAlk for the inorganic carbon cycle include the sum of ${ }^{12} \mathrm{C}$ and ${ }^{13} \mathrm{C}$. Explicit ${ }^{13} \mathrm{C}$ concentrations are computed from the spin-up through the requirement that the pre-industrial atmospheric $\delta^{13} \mathrm{C}$ has a value of $-6.5 \%$. The continental input rate of ${ }^{13} \mathrm{C}$ and the corresponding output rate through sediment accumulation were iteratively determined, so that in the final model spin-up the ${ }^{12} \mathrm{C}$ and ${ }^{13} \mathrm{C}$ are fully compatible with the pre-industrial $\delta^{13} \mathrm{C}$ value. 

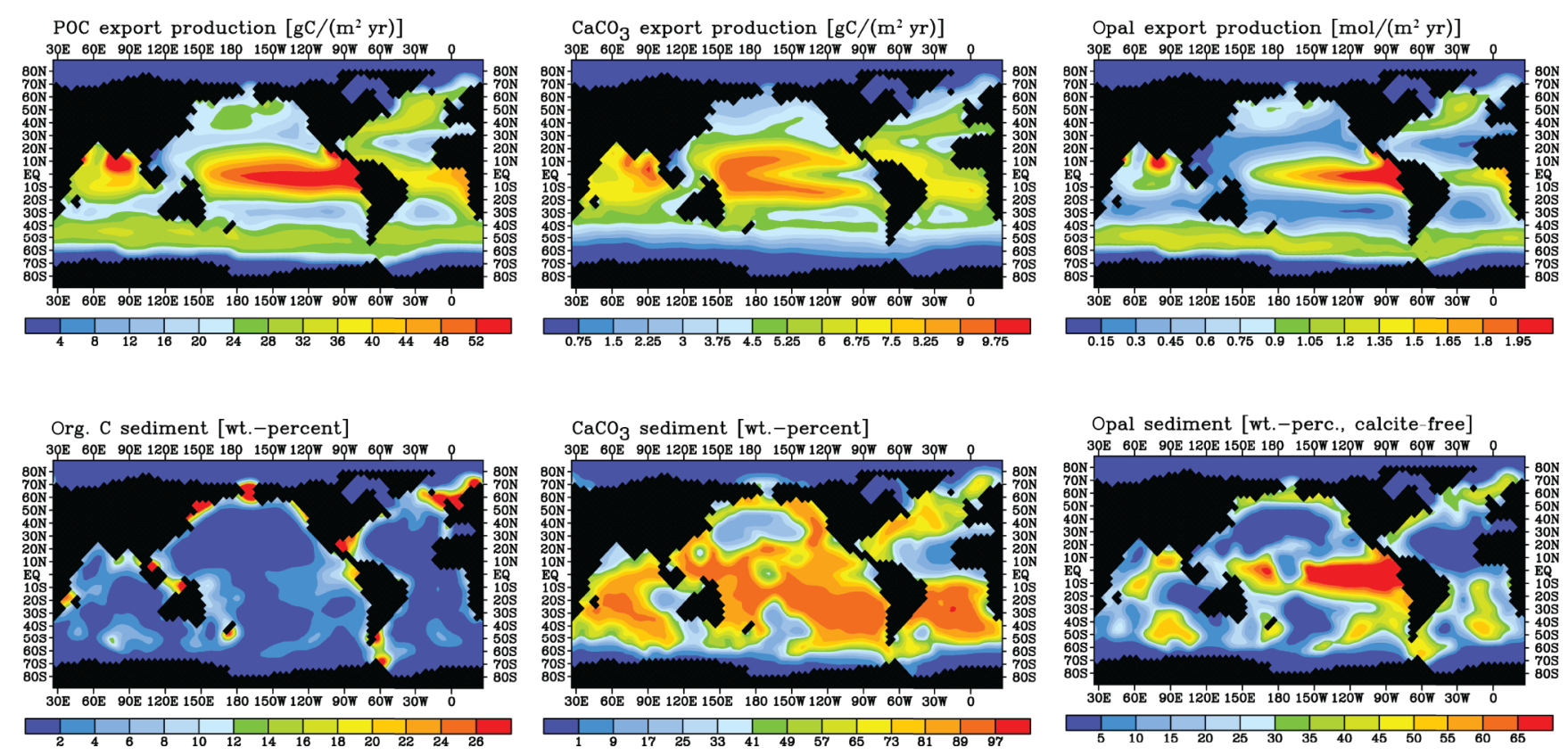

Figure 1. Export production rates and average surface sediment distributions for the control run.

\subsection{Control run}

Important global bulk numbers for the quasi-equilibrium state of the 100000 -year-long control run are given in Table 1. For illustration of the control performance, examples for the export production rates and the respective sediment components are provided in Fig. 1. Meridional cross sections for dissolved inorganic phosphate, carbonate ion concentration, and $\delta^{13} \mathrm{C}$ of total dissolved inorganic carbon are shown in Fig. 2. The model is able to reproduce the major characteristics of global tracer distributions, with decreasing deepwater carbonate ion concentrations and $\delta^{13}$ values as well as increasing phosphate concentrations from the Atlantic to the Pacific Ocean. Simulated tracer patterns appear to be more smoothed as compared to the observations because of the coarse spatial resolution of the model. The $\mathrm{CaCO}_{3}$ sediment distribution in the northern Pacific Ocean may show somewhat too high $\mathrm{CaCO}_{3}$ wt $\%$ as compared with observations. Based on experience with previous simulations, the $\mathrm{CaCO}_{3}$ content of the sediment mixed layer appears to react quite sensitively to the degree of undersaturation and the redissolution rate constants chosen. Therefore, a slight overestimate of $\mathrm{CaCO}_{3}$ sediment in the control run avoids a potential complete dissolution of $\mathrm{CaCO}_{3}$ for many grid points during the sensitivity experiments.

\section{Sensitivity experiments}

In order to determine how the governing process parameters of the carbon cycle changed from the cold, low- $\mathrm{CO}_{2}$ world to the warmer and higher $\mathrm{CO}_{2}$ pre-industrial world, we first
Table 1. Global bulk numbers for the model control run.

\begin{tabular}{|c|c|}
\hline Global value & $\begin{array}{r}\text { Control run } \\
\text { value }\end{array}$ \\
\hline Atmospheric $p \mathrm{CO}_{2}(\mu \mathrm{atm})$ & 284.0 \\
\hline POC export production $\left(\mathrm{Pg} \mathrm{C} \mathrm{yr}^{-1}\right)$ & 9.60 \\
\hline 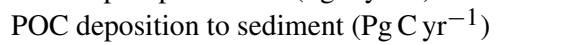 & 0.088 \\
\hline POC accumulation in sediment $\left(\mathrm{Pg} \mathrm{Cy}^{-1} \mathrm{r}\right)$ & 0.060 \\
\hline 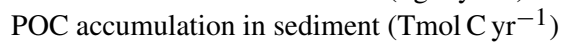 & 5.000 \\
\hline $\mathrm{CaCO}_{3}$ export production $\left(\mathrm{Pg} \mathrm{C} \mathrm{yr}^{-1}\right)$ & 1.72 \\
\hline $\mathrm{CaCO}_{3}$ deposition $\left(\mathrm{Pg} \mathrm{C} \mathrm{yr}^{-1}\right)$ & 0.37 \\
\hline $\mathrm{CaCO}_{3}$ accumulation $\left(\mathrm{Pg} \mathrm{C} \mathrm{yr}^{-1}\right)$ & 0.32 \\
\hline $\mathrm{CaCO}_{3}$ accumulation $\left(\mathrm{Tmol} \mathrm{C} \mathrm{yr}^{-1}\right)$ & 27.0 \\
\hline 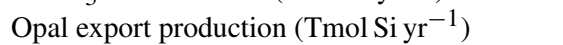 & 251 \\
\hline 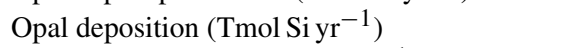 & 13.7 \\
\hline Opal accumulation (Tmol Si yr ${ }^{-1}$ ) & 4.5 \\
\hline
\end{tabular}

carried out a suite of sensitivity experiments with the full 3D carbon cycle model. In each run, we change only one of the governing parameters in order to determine the respective change in the biogeochemical system. In particular, we are interested in the respective change in the inorganic as well as organic carbon cycle and how these changes are imprinted onto the simulated palaeoclimatic record. In a previous study Heinze et al. (1991) carried out sensitivity experiments with an earlier version of HAMOCC and also compared the results with data from the observational palaeoclimatic archive. The present study, however, differs significantly from the previous approach. In Heinze et al. (1991) only equilibrium responses of the biogeochemical state to instantaneous parameter changes (permanent switch from one 

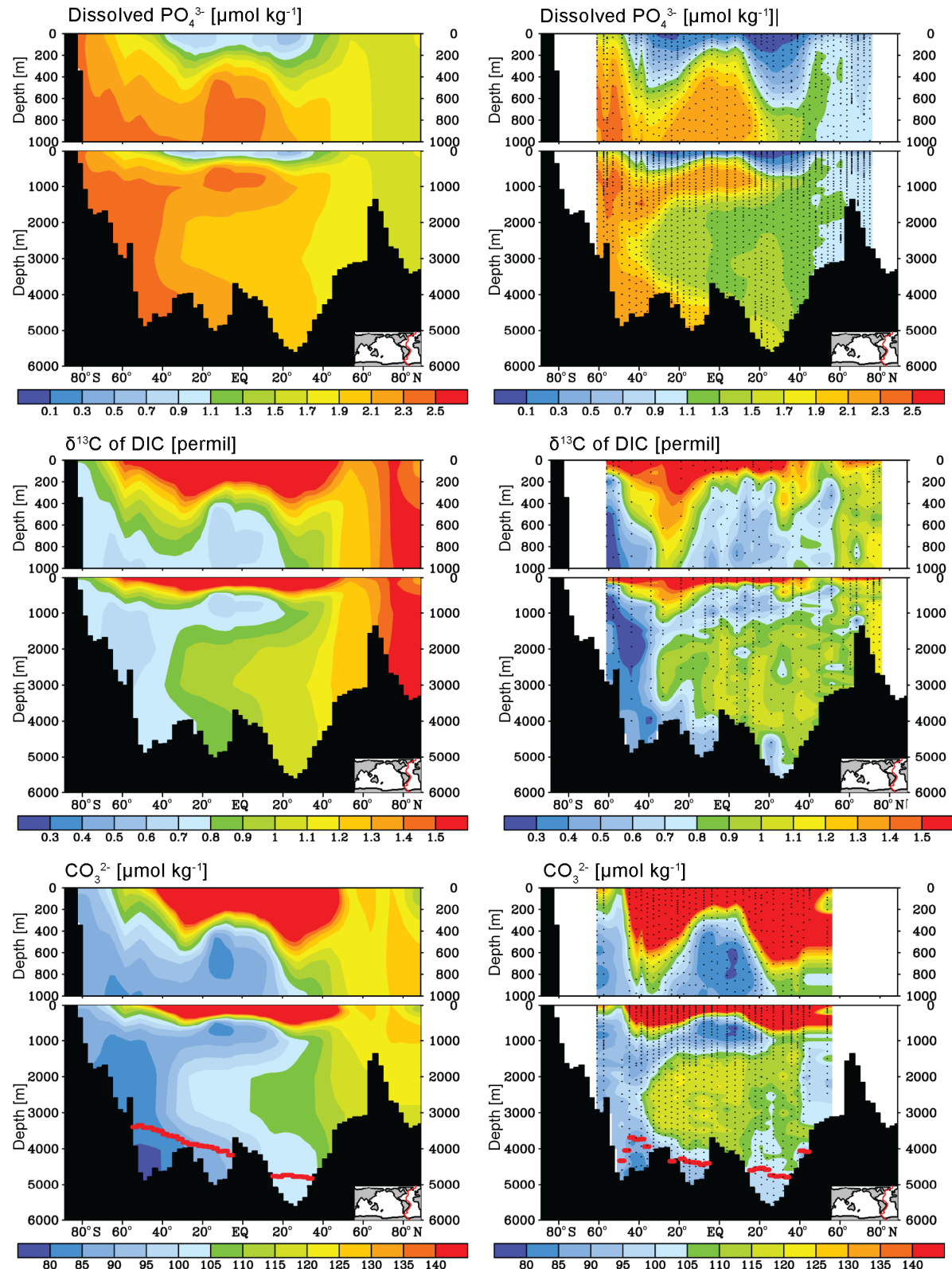

Figure 2. Atlantic Ocean cross sections for the model control run (left column) and observations from the GEOSECS programme (Bainbridge, 1981) (right column). Top: dissolved phosphate. Centre: $\delta^{13} \mathrm{C}$ of total dissolved inorganic carbon. Bottom: carbonate ion concentration.

of the control run configurations) were tested, the alternative velocity field used did not resemble the glacial ocean very well, and the model did not include an interactive early diagenesis sub-model (only interactive bulk sediment reservoirs which did not allow for varying total system inventories). The last of these issues thus only allowed a comparison between the modelled tracer values and sediment-corederived "proxy data". Also the fixed total system inventory of carbon, nutrients, and alkalinity allowed a limited range of system changes. The first study of HAMOCC including an interactive diagenesis module by Archer and Maier-Reimer
(1994) has already revealed the higher sensitivity of such a model configuration, as the water column tracer inventory could vary considerably more dynamically.

We first carried out a control run over the past 130000 years, restarting from the standard spin-up of the model. This control run revealed the excellent mass conservation and also the almost drift-free ${ }^{13} \mathrm{C}$ distributions in all reservoirs. Thereafter, a series of simulations with perturbed model parameters were conducted by restarting from the same pre-industrial control run. The runs were started from "Eemian" conditions which we assumed to be similar to the 
Table 2. Parameter changes $x_{j}, j=1, \ldots, n ; n=8$ as imposed in the sensitivity experiments with the full 3-D biogeochemical model relative to the control run parameter choice. The $x_{j}$ are the maximum amplitude of change for the respective strongest excursion of the observed $\delta \mathrm{D}$ curve at the LGM.

\begin{tabular}{lll}
\hline$j$ & Parameter description & $\begin{array}{l}\text { Value of } \\
\text { param. } \\
\text { change } \\
x_{j}\end{array}$ \\
& & \\
\hline 1 & $\begin{array}{l}\text { Sea surface temperature for computation } \\
\text { of the chemical and biological constants: }\end{array}$ & $-5^{\circ}$ \\
2 & Loss in carbon stock of the terrestrial biosphere: & $-1000 \mathrm{PgC}$ \\
3 & Dissolution rate constants of POC: & $-10 \%$ \\
4 & Dissolution rate constants of $\mathrm{BSi}^{\circ}$ & $-10 \%$ \\
5 & Export production rain ratio $\mathrm{CaCO}_{3}$ : POC: & $-10 \%$ \\
6 & 3-D oceanic velocity field: & $100 \%$ glacial field \\
& Glacial dust deposition and associated stimulation & \\
7 & of biological export production: & $100 \%$ glacial field \\
8 & Redfield ratio C:P & $+15 \%$ \\
\hline
\end{tabular}

pre-industrial state as resulting from the HAMOCC spin-up. We then scaled the various parameter perturbations with the $\delta \mathrm{D}$ temperature record of the EPICA Dome $\mathrm{C}$ ice core project (Jouzel, 2004) assuming that all carbon cycle variations during the past climatic cycle are correlated either with temperature or with the rather similar temporal pattern of the atmospheric $\mathrm{CO}_{2}$ variation. There are uncertainties associated with this assumption, as the Antarctic air temperature record is a localised record and may not reflect global temperature change, and also because ocean temperatures may lag behind this signal. On the other hand, the local Antarctic $\delta \mathrm{D}$ temperature record is highly correlated with the global atmospheric $p \mathrm{CO}_{2}$ signal (Siegenthaler et al., 2005; Barnola et al., 1987; Jouzel et al., 1987). The seawater temperature change would probably not lag too long behind this signal if reasonably long time intervals are considered. Due to the close correlation between air temperature and atmospheric $p \mathrm{CO}_{2}$ over the past glacial-interglacial cycle, we cannot strictly discriminate between drivers for ocean and land carbon cycle changes coming from physical (temperature) and biogeochemical forcings ( $p \mathrm{CO}_{2}$, carbonate saturation, $\mathrm{pH}$ value), but we need to justify this independently for the different parameters under investigation. For the sensitivity experiments, we selected the following governing model parameters of the carbon cycle: (1) the sea surface temperature for computation of the chemical and biological constants, (2) the release/uptake of carbon from/by the terrestrial biosphere, (3) the degradation rate constant of POC in the water column, (4) the dissolution rate constant of $\mathrm{BSi}$ in the water column, (5) the export production rain ratio $\mathrm{CaCO}_{3}: \mathrm{POC}$, (6) the 3D oceanic velocity field, (7) the glacial dust deposition and associated stimulation of biological export production, and (8) the Redfield ratio C:P.

These parameter changes are summarised in Fig. 3 and Table 2 and described in more detail below.

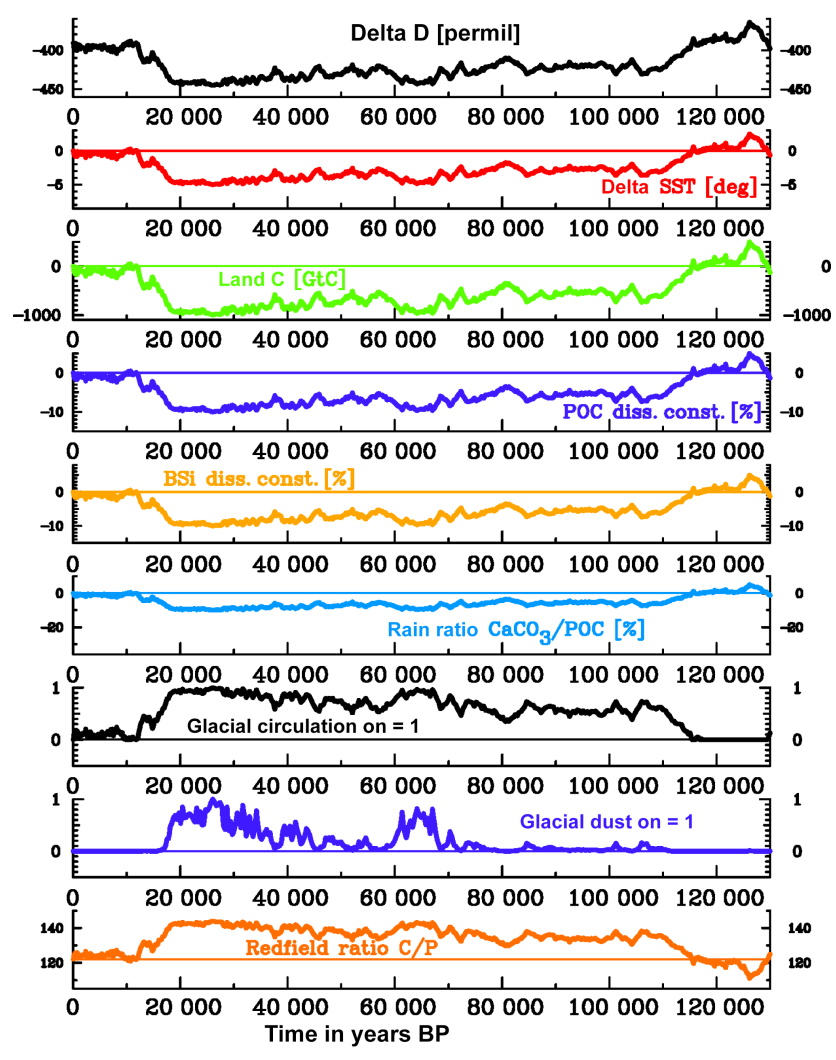

Figure 3. Prescribed parameter changes for the sensitivity experiments with the biogeochemical ocean model.

\subsection{Sea surface temperature for computation of the chemical and biological constants}

In this experiment, we reduced the sea surface temperature up to a maximum change of $5 \mathrm{~K}$ (with the consideration that the minimum temperature stays at or above the freezing point of sea water) only for the computation of the temperaturedependent chemical and biological parameters in the model, which usually all have their fixed control run values. The effect on the $\mathrm{CO}_{2}$ solubility is relatively strong, accounting for ca. $12 \mathrm{ppm}$ change in atmospheric $p \mathrm{CO}_{2}$ for a $1 \mathrm{~K}$ change in sea water temperature (see Broecker and Peng, 1986). The $5 \mathrm{~K}$ change in temperature is approximately the maximum change that can be expected on the basis of stable oxygen isotopes or other temperature indicators (e.g. Stute et al., 1995).

\subsection{Release/uptake of carbon from/by the terrestrial biosphere}

Variations in the land carbon cycle also need to be properly taken into account for the overall $p \mathrm{CO}_{2}$ signal in the atmosphere and the imprint of ${ }^{13} \mathrm{C}$ on the sedimentary record. We do not explicitly model the terrestrial carbon cycle in our experiment. Rather, we assume here that the land biosphere would have a smaller net primary production (Hoogakker et al., 2016) and standing biomass stock and hence provide 
a release of carbon to the atmosphere under colder and drier conditions. The amplitude for biomass carbon loss from the land biosphere to the atmosphere was set to $-1000 \mathrm{Pg} \mathrm{C}$, in line with estimates from terrestrial palaeoclimate records according to Crowley (1995). A potentially increased storage of organic carbon under the ice sheets and at cold conditions (lower bacterial activity for plant biomass degradation) is also being discussed (e.g. Zeng, 2003). Such storage could lower the overall carbon loss from the terrestrial biosphere under glacial conditions.

\subsection{Dissolution rate constants of $\mathrm{POC}$ and $\mathrm{BSi}$}

We explored the temperature effect on both sinking particulate organic carbon as well as biogenic silica. We assumed that the degradation of both substances slows down under lower temperatures due to thermodynamic effects as well as decreasing bacterial decomposition (Turley and Mackie, 1995; Van Cappellen et al., 2002, Bidle and Azam, 1999). Through the respective parameter changes we separately tested a strengthening of the biological carbon pump and of the silicon pump, which would have led to a deeper penetration of carbon and nutrients into the water column under glacial conditions ("vertical fractionation" as described by Boyle, 1988a, and Boyle, 1988b). We chose a maximum decrease in degradation strength of $10 \%$.

\subsection{Export production rain ratio $\mathrm{CaCO}_{3}: \mathrm{POC}$}

A decrease in rain ratio has been suggested as one of the potential mechanisms to extract carbon from the atmosphere during glacial times (Berger and Keir, 1984). A reduction in the $\mathrm{CaCO}_{3}$ production to zero could potentially explain half of the glacial $p \mathrm{CO}_{2}$ drawdown from the atmosphere (Broecker and Peng, 1986). However, the experiments by Zondervan et al. (2001) and Riebesell et al. (2000) would suggest the opposite: in a low- $\mathrm{CO}_{2}$ world, the $\mathrm{CaCO}_{3}$ : POC ratio would be expected to increase. This would make it more difficult to explain the glacial $\mathrm{CO}_{2}$ uptake by the oceans. Heinze and Hasselmann (1993) showed that this is possible in principle. In our experiment here, however, we follow the idea of a diminished $\mathrm{CaCO}_{3}$ : $\mathrm{POC}$ export production rain ratio during glacial times. In order to get a pronounced signal, we decrease the amplitude to a $-10 \%$ change at the LGM with respect to the control run.

\subsection{3-D oceanic velocity field}

Practically all geochemically relevant palaeoclimate tracers in the ocean depend on the ocean circulation. Therefore, it is necessary to take a realistic glacial velocity field into account in order to provide the correct addition to tracer changes which may be induced by biological and chemical processes. Here, we follow the same approach as outlined in Heinze (2001), where we "mix" the velocity, thermohaline, convec- tive mixing, and sea ice margin values from two different runs of the dynamical ocean general circulation model LSG (Large Scale Geostrophic; Maier-Reimer et al., 1993). These runs are the respective interglacial and glacial first-guess runs from Winguth et al. (1999) which show major features of the pre-industrial as well as LGM distributions of the $\delta^{13} \mathrm{C}$ of dissolved inorganic carbon. As the maximum amplitude for the velocity field change we assume a full switch to LGM conditions at the largest negative excursion of the $\delta \mathrm{D}$ EPICA Dome $\mathrm{C}$ ice core curve. It would be preferable to have respective atmospheric forcing fields available to have a better constraint on the velocity fields at hand. However, the considerable effort required to realise such a run (which would need to be carried out with the full seasonally resolving LSG model) was deemed too large for our study here. The "kinematic" approach chosen here should work for practical reasons as the respective $\delta^{13} \mathrm{C}$ distributions of DIC show realistic patterns.

\subsection{Glacial dust deposition}

We carried out a number of sensitivity tests concerning the effect of a change in continental dust deposition onto the sea surface. First, we only tested the pure effect of clay addition through dust by applying the glacial dust deposition field by Mahowald et al. (1999) at the LGM and respective mixtures of interglacial and glacial dust deposition fields at other time intervals. As the dust records of marine sediment core records usually do not follow the pattern of the $\delta \mathrm{D}$ record (e.g. Fig. 4 of Carter and Manighetti, 2006), we scaled the change in dust supply with the sixth order of the glacialinterglacial difference of the $\delta \mathrm{D}$ curve, i.e. assumed a sudden increase in dustiness only at very low temperatures. Again, we set a maximum value of dust change to $100 \%$ glacial conditions at the LGM and smaller changes elsewhere (see Fig. 3). The effect of this dust addition would be a change in the dilution of the sediment weight percentages of the reactive sedimentary material by inert clay and also a change in the local sediment accumulation rates. It has been suggested that a stimulation of biological export production through increased dust and iron deposition to the ocean surface under glacial conditions could occur (e.g. Martin et al., 1994; Berger and Wefer, 1991). In an additional experiment, the maximum uptake velocities for phosphorus, carbon, and silica were scaled with the glacial-interglacial difference of the dust deposition as provided by Mahowald et al. (1999). For the results of the fitting procedure as shown below, we considered here the run with the dilution effect only in order to separate sediment dilution effects on the $\mathrm{CaCO}_{3}$ sediment concentration from those caused by an increase in biological production. 


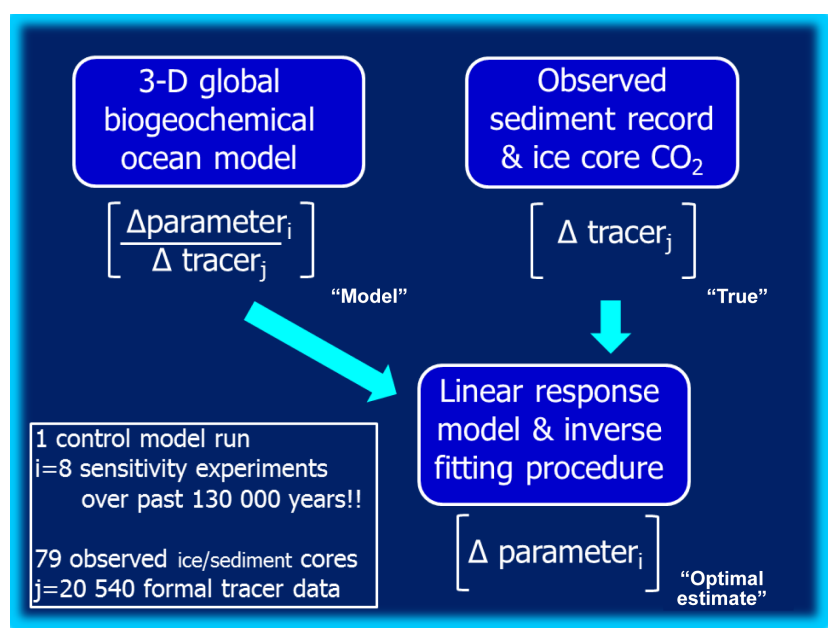

Figure 4. Fitting procedure combining the observed palaeoclimate data and the model-derived information on how the downcore distributions of the various cores look for the different sensitivity experiments.

\subsection{Redfield ratio C : P}

Finally, we allowed carbon over- or underconsumption in response to the interglacial to glacial change in environmental conditions. Riebesell et al. (2007) and Bellerby et al. (2008) postulated an increasing carbon overconsumption $\mathrm{C}: \mathrm{N}$ under high- $\mathrm{CO}_{2}$ conditions resulting from a mesocosm experiment. Conversely, a change towards increasing carbon overconsumption during the glacial low- $\mathrm{CO}_{2}$ world has been suggested as a powerful mechanism to account for the glacial $\mathrm{CO}_{2}$ drawdown and at the same time cause a plausible foraminiferal $\delta^{13} \mathrm{C}$ signal (e.g. Shackleton and Pisias, 1985; Broecker, 1982; Broecker and Peng, 1986; Heinze and Hasselmann, 1993). In our sensitivity experiment we investigated the possibility for an increase in carbon overconsumption by imposing an increase in the Redfield ratio $\mathrm{C}: \mathrm{P}$ homogeneously over the ocean. We specified a maximum change of $15 \%$ at the LGM (see Fig. 3, lowermost panel).

We try to make a reasonable trade-off between the number of free parameters and the need for inclusion of the most essential parameters which contribute to the tracer variations in the palaeo-record. Thus, we aim to isolate imprints of parameter variations in the observed sedimentary record which would otherwise be masked by further independent processes (e.g. it would be futile to derive changes in biological pump strength from the foraminiferal $\delta^{13} \mathrm{C}$ distribution in the ocean without taking into account respective changes in the ocean currents which also affect the marine $\delta^{13} \mathrm{C}$ distribution).

For determining the most likely choice of the governing parameters, we analysed modelled output for a series of palaeoclimatic data sets. First of all, the model delivers prognostic atmospheric $p \mathrm{CO}_{2}$ values for each sensitivity experiment relative to the control run during each time step for comparison with the Antarctic ice core records. The model runs were started from year $129536 \mathrm{BP}$ and integrated until the present. This start year was chosen so that the first and last $\delta \mathrm{D}$ values are close to each other and no anthropogenic $\mathrm{CO}_{2}$ emissions were imposed during the very last part of the integration. Each run requires around 4 days of CPU time on an advanced UNIX work station. Using the methodology of Heinze et al. (2009) the model at each grid point accumulates sediment in a continuous way for the components $\mathrm{CaCO}_{3}$, opal, organic carbon, clay, and organic phosphorus. $\delta^{13} \mathrm{C}_{\text {planktonic }}$ and $\delta^{13} \mathrm{C}_{\text {benthic }}$ of the $\mathrm{CaCO}_{3}$ fraction and the individual ages of each sediment component plus the atmospheric $\mathrm{CO}_{2}$ partial pressure were stored together with the actual accumulation rates at the base of the sediment mixed layer. In order to reduce the amount of data output, we only stored 100-year averages. Over the integration time period, for each run a continuous temporally varying sediment stratigraphy is built up. After the model runs, we "drill" into this synthetic sediment and "recover" simulated sediment cores for comparison with the observations from real world sediment core data. We can provide such modelled cores at every grid point of the model individually.

\section{Linear response model, observational sediment core database, and fitting procedure}

The inverse modelling procedure as applied and described here, draws on many aspects of the work by Heinze and Hasselmann (1993). We partly repeat some of the methodological issues here in order to avoid the reader having to refer too often to a separate study when reading this analysis here. The method is illustrated in Fig. 4. We carried out a total of eight sensitivity experiments with the full 3-D BOGCM, providing eight different data sets for respective changes in 79 different tracer time series (see below), resulting formally in a total of 20540 modelled tracer values and the same number of respective observed values (for each run). The eight sensitivity experiments represent the response of the full 3D model to variations of $n=8$ governing input parameters $x_{j}(j=1, \ldots, n)$ (Table 2$)$, resulting in $m=20540$ palaeoclimate tracer record changes $g_{i}(i=1, \ldots, m)$ as induced in these experiments as a consequence of the changes $x_{j}$ of the parameters.

The resulting linear response model thus consists of the matrix describing the linearised relation between perturbations of the input and output variables. The model output variables $\hat{g_{i}}$ in the sensitivity experiments correspond to the observed perturbations of the atmospheric $\mathrm{CO}_{2}$ record and the sediment records of $\mathrm{CaCO}_{3}, \delta^{13} \mathrm{C}_{\text {benthic }}, \delta^{13} \mathrm{C}_{\text {planktonic }}$, and opal (BSi) (see following subsection).

In the full non-linear BOGCM, the palaeoclimate tracers $G_{i}$ are functions of the governing model parameters $X_{j}$,

$G_{i}=F_{i}\left(X_{j}\right)$.

In the simplified linear response model, the relation (Eq. 1) is Taylor-expanded (and then truncated) about a reference state 
$X_{j}=X_{j}^{0}, G_{i}=G_{i}^{0}$ as given by the standard run (with zero parameter changes):

$\hat{g}_{i}=\sum_{j=1}^{n} A_{i j} x_{j}$

where $\hat{g}_{i}=G_{i}-G_{i}^{0}, x_{j}=X_{j}-X_{j}^{0}$, and $A_{i j}=\frac{\partial F_{i}}{\partial X_{j}}\left(X_{j}^{0}\right)$. The response coefficients $A_{i j}$ form the elements of the model matrix A. These response coefficients resulted from the model sensitivity experiments under the assumption of a linear relation between the parameter changes $x_{j}$ and the response vector $\hat{g}_{i}$ predicted in every sensitivity experiment $j$.

\subsection{Database of observations from the palaeoclimate record}

For calibrating the free model parameters, we employ a database of palaeoclimatic records as summarised in Tables 3 and 4. Locations are indicated in Fig. 5. Most of the $\delta^{13} \mathrm{C}_{\text {benthic }}$ and $\delta^{13} \mathrm{C}_{\text {planktonic }}$ data were taken from the compilation of Oliver et al. (2010). The majority of $\mathrm{CaCO}_{3} \mathrm{wt} \%$ data were taken from a compilation by B. B. A. Hoogakker and H. Elderfield (personal communication, 2013), Table 4). Further marine sediment core data $\left(\delta^{13} \mathrm{C}_{\text {benthic }}, \delta^{13} \mathrm{C}_{\text {planktonic }}\right.$, $\mathrm{BSi}$, and $\mathrm{CaCO}_{3}$ wt \%) were taken from various literature sources (see references in Tables 3 and 4). For atmospheric $p \mathrm{CO}_{2}$ we use the Vostok ice core signal from Antarctica (Barnola et al., 1987). We did not explicitly synchronise the different palaeoclimatic time series to a common age model here but rather took the measurement-age combinations at face value. We estimate the error due to this to up to a few thousand years (compare the discussion in Oliver et al., 2010). As we are not interested here in exact timing and phase shifts of signals in different variables, and due to the overall errors in the modelling approach (coarse resolution model, only crude representation of circulation changes, assumption that pre-industrial model state also corresponds to the Eemian), we assume that this approach is reasonable. Some sediment core data were even extracted by hand from published images. However, most of the $\delta^{13} \mathrm{C}_{\text {benthic }}$ and $\mathrm{CaCO}_{3}$ wt \% time series employed were synchronised in respective data compilations. For the fitting procedure, we interpolated all observed data to regular time series with an increment of 500 years (260 equidistant data points in time).

Modelled annual global mean values of atmospheric $p \mathrm{CO}_{2}$ were compared for comparison with the Vostok $p \mathrm{CO}_{2}$ signal. The corresponding model time series data of the different sediment palaeoclimate tracer curves were extracted from the respective model grid point closest to the location of real sediment core extraction for the various model sensitivity experiment runs. Modelled sediment data were interpolated with respect to age onto the same 500-year points as the observations. The age of each sediment component was simulated according to Heinze et al. (2009) during the sen- sitivity experiments and stored together with the simulated depth in the core of each modelled sediment variable.

For the fitting procedure, observed and modelled data were translated to changes relative to the pre-industrial period. Thus, we analysed the changes in the tracers relative to this reference, while the respective parameter changes were taken as changes relative to the control run values.

\subsection{Fitting procedure}

Our general fitting procedure closely follows the method as described in Heinze and Hasselmann (1993).

\subsubsection{The general minimisation problem}

We fitted the linearly modelled palaeoclimatic tracer changes $\hat{g}_{i}$ to the observed tracer changes $g_{i}$ through minimising the mean square sum $Q^{2}$ of the individual tracer errors $\epsilon_{i}=\hat{g}_{i}-$ $g_{i}$ :

$$
\begin{aligned}
Q^{2}=\sum_{i=1}^{m} \epsilon_{i}^{2} & =\sum_{i=1}^{m}\left(\sum_{j=1}^{n} A_{i j} x_{j}-g_{i}\right)^{2} \\
& =\left(\cdot \boldsymbol{x}^{T}|| \mathbf{A}^{T}\left|-\boldsymbol{g}^{T}\right|\right)(|\mathbf{A} \| \boldsymbol{x} \cdot-| \boldsymbol{g} \cdot) .
\end{aligned}
$$

The dimensions of the vectors and matrices are described by the following symbols (see Heinze and Hasselmann, 1993): the left marker of a matrix symbol denotes the number of rows, the right marker specifies the number of columns. In our specific case, the marker "." corresponds to 1 , "|" to the number $m=20540$ of observed tracer data, and "" to the number $n=8$ of parameter changes $x_{j}$ to be estimated. The solution $\mid \hat{x}$. which minimises the mean square expression $Q^{2}$ is derived through the necessary condition $\frac{\mathrm{d} Q^{2}}{\mathrm{~d} x}=0$ :

${ }_{\mid \mathbf{A}^{T}}\|\mathbf{A}\| \hat{\boldsymbol{x}} \cdot=\mid \mathbf{A}^{T} \| \boldsymbol{g}$,

which can also be written as

$\hat{\boldsymbol{x}} \cdot=\left(\left|\mathbf{A}^{T} \| \mathbf{A}\right|\right)^{-1} \mathbf{A}^{T} \| \boldsymbol{g} \cdot$

Through one realisation of the fitting procedure we thus, simultaneously, determined all eight optimal parameter changes $\hat{x}_{j}$ necessary for a best possible reproduction of the observed tracer changes. In addition, the procedure yields a time series of residual errors $\epsilon_{i}$ which quantify the expected remaining discrepancies between modelled and observed tracers after the optimisation (we write here "expected" as the non-linear model may result in somewhat different residuals than the linear response model). Our problem is formally overdetermined where $m=20540$ tracer data points must be fitted with $n=8$ parameters. Therefore, the least-squares formulation of our solution procedure is appropriate.

The error expression of Eq. (3) is defined with a simple unit matrix norm. The more general maximum likelihood 
Table 3. Marine sediment core data and ice core data which were used for determining the parameter changes through a fit of the linear response model. Most data sets were taken from the data synthesis by Oliver et al. (2010) as indicated below. (For $\mathrm{CaCO}_{3}$ data, see Table 4.)

\begin{tabular}{|c|c|c|c|c|c|c|}
\hline $\begin{array}{l}\text { Core } \\
\text { name }\end{array}$ & Area & $\begin{array}{r}\text { Lat } \\
+\mathrm{N},-\mathrm{S}\end{array}$ & $\begin{array}{r}\text { Long } \\
-\mathrm{W},+\mathrm{E}\end{array}$ & $\begin{array}{r}\text { Depth } \\
(\mathrm{m})\end{array}$ & Record used & Reference \\
\hline Vostok & Antarctica & -78 & -106 & -3488 & at. $\mathrm{CO}_{2}$ & Barnola et al. (1987) \\
\hline M13519 & Eq. Atlantic & 5.333 & -19.183 & n.giv. & $\delta^{13} \mathrm{C}_{\text {benthic }}$ & Sarnthein et al. (1984) \\
\hline RC13-1110 & Eq. Pacific & 0.100 & -95.650 & 3231 & $\delta^{13} \mathrm{C}_{\text {benthic }}$ & $\operatorname{Mix}(1991)$ \\
\hline EW9209-1JP & N Atlantic & 5.0 & -43.0 & 4056 & $\delta^{13} \mathrm{C}_{\text {benthic }}$ & Oliver et al. (2010); Curry and Oppo (1997) \\
\hline GEOB1115-3 & S Atlantic & -3.56 & -12.56 & 2945 & $\delta^{13} \mathrm{C}_{\text {benthic }}$ & Oliver et al. (2010); Bickert and Wefer (1996) \\
\hline GEOB1721-6 & S Atlantic & -29.17 & 13.08 & 3044 & $\delta^{13} \mathrm{C}_{\text {benthic }}$ & Oliver et al. (2010); Bickert and Mackensen (1996) \\
\hline GEOB $1722-3$ & S Atlantic & -29.49 & 11.75 & 3073 & $\delta^{13} \mathrm{C}_{\text {benthic }}$ & Oliver et al. (2010); Mollenhauer et al. (2002) \\
\hline GIK13519-1 & N Atlantic & 5.67 & -19.85 & 2862 & $\delta^{13} \mathrm{C}_{\text {benthic }}$ & Oliver et al. (2010); Sarnthein et al. (1994) \\
\hline GIK23414-9 & N Atlantic & 53.54 & -20.29 & 2196 & $\delta^{13} \mathrm{C}_{\text {benthic }}$ & Oliver et al. (2010); Jung and Sarnthein (2003b) \\
\hline GIK23415-9 & N Atlantic & 53.18 & -19.14 & 2472 & $\delta^{13} \mathrm{C}_{\text {benthic }}$ & Oliver et al. (2010); Jung and Sarnthein (2003a) \\
\hline KNR140-37J & $\mathrm{N}$ Atlantic & 31.41 & -75.26 & 3000 & $\delta^{13} \mathrm{C}_{\text {benthic }}$ & Oliver et al. (2010); Keigwin (2004) \\
\hline ODP1087 & S Atlantic & -31.46 & 15.31 & 1372 & $\delta^{13} \mathrm{C}_{\text {benthic }}$ & Oliver et al. (2010); Pierre et al. (2004) \\
\hline GEOB3004-1 & Indian Oc. & 14.61 & 5292. & 1803 & $\delta^{13} \mathrm{C}_{\text {benthic }}$ & Oliver et al. (2010); Schmiedl and Mackensen (2006)) \\
\hline MD01-2378 & Indian Oc. & -13.08 & 121.79 & 1783 & $\delta^{13} \mathrm{C}_{\text {benthic }}$ & Oliver et al. (2010); Kawamura et al. (2006) \\
\hline MD97-2121 & S Pacific & -40.38 & 177.99 & 3014 & $\delta^{13} \mathrm{C}_{\text {benthic }}$ & Oliver et al. (2010); Carter et al. (2008) \\
\hline M13519 & Eq. Atlantic & 5.333 & -19.183 & n.giv. & $\delta^{13} \mathrm{C}_{\text {planktonic }}$ & Sarnthein et al. (1984) \\
\hline V19-30 & Eq. Pacific & -3.350 & -83.350 & 3091 & $\delta^{13} \mathrm{C}_{\text {planktonic }}$ & Shackleton and Pisias (1985) \\
\hline GIK17049-6 & N Atlantic & 55.26 & -26.73 & 3331 & $\delta^{13} \mathrm{C}_{\text {planktonic }}$ & Oliver et al. (2010); Jung and Sarnthein (2004a) \\
\hline GIK23415-9 & $\mathrm{N}$ Atlantic & 53.18 & -19.14 & 2472 & $\delta^{13} \mathrm{C}_{\text {planktonic }}$ & Oliver et al. (2010); Jung and Sarnthein (2003a) \\
\hline GIK23418-8 & $\mathrm{N}$ Atlantic & 52.55 & -20.33 & 1491 & $\delta^{13} \mathrm{C}_{\text {planktonic }}$ & Oliver et al. (2010); Jung and Sarnthein (2004b) \\
\hline ODP1089 & S Atlantic & -40.94 & 9.89 & 4621 & $\delta^{13} \mathrm{C}_{\text {planktonic }}$ & Oliver et al. (2010); Hodell et al. (2003b) \\
\hline $\mathrm{RC} 13-138$ & Eq. Pacific & 1.81 & -94.14 & 2655 & $\delta^{13} \mathrm{C}_{\text {planktonic }}$ & Oliver et al. (2010); (Delphiprojekt; Dürkoop et al., 1997) \\
\hline C4402 & W Pacific & 2.996 & 135.022 & 4402 & $\mathrm{BSi}$ & Kawahata et al. (1998) \\
\hline H3571 & N Pacific & 34.904 & 179.703 & 3571 & $\mathrm{BSi}$ & Kawahata et al. (2000) \\
\hline RC24-07 & Eq. Atlantic & -1.350 & -11.917 & 3899 & $\mathrm{BSi}$ & Verardo and McIntyre (1994) \\
\hline $503 \mathrm{~B}$ & E. eq. Pac. & 4.8 & -95.6 & 3672 & $\mathrm{BSi}$ & Rea et al. (1986) \\
\hline
\end{tabular}

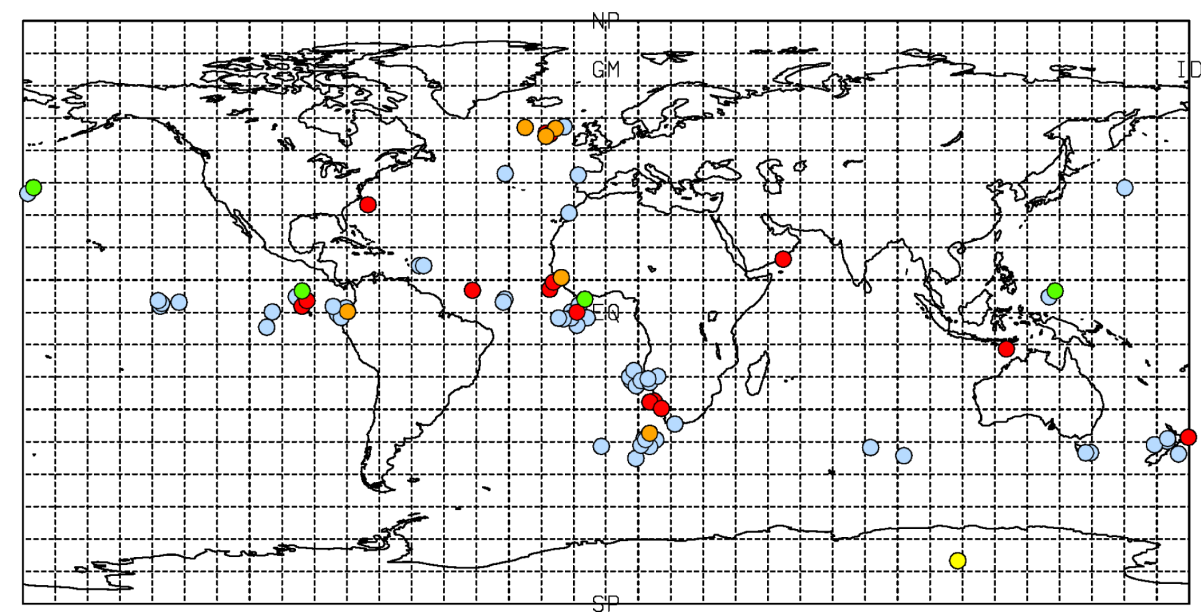

Figure 5. Locations of the palaeoclimate observations (sediment core, ice core) as used in the inverse approach: atmospheric $\mathrm{CO}_{2}$ (yellow), $\delta^{13} \mathrm{C}_{\text {benthic }}$ (red), $\delta^{13} \mathrm{C}_{\text {planktonic }}$ (orange), $\mathrm{BSi}$ wt $\%$ (green), and $\mathrm{CaCO}_{3} \mathrm{wt} \%$ (blue).

norm would be given by the inverse of the covariance matrix of the measurement errors (e.g. Martin, 1971). In Eq. (3), we make the assumption that the errors are uncorrelated and have the same variance. At present, we have no conclusive means for estimating the error correlation. Therefore, the as- sumption of a simple unit matrix norm is reasonable here. However, we normalised the variables $g_{i}$ by the mean absolute values of the respective tracer over the past climatic cycle, so that differential weighting of different tracer records, for example due to use of different physical units, is avoided. 


\subsubsection{The SVD least-squares solution}

In many inverse problems it is not possible to determine a physically meaningful least-squares solution directly from Eq. (4). The solution can be contaminated by noise if the model matrix $|\mathbf{A}|$ is badly conditioned. This leads, in practice, to unrealistically high variations in the optimised parameter changes if these depend only on very small variations in the tracer changes. Beforehand, it cannot be seen whether $\mathbf{A}$ is badly conditioned or not. Therefore, we applied the singular value decomposition (SVD) technique which provides a quantitative treatment of the noise problem. For an introduction to this technique, see the very useful work by Wunsch (1989). The model matrix $\mathbf{A}$ is decomposed into a product of three matrices (SVD; see Lanczos, 1961):

$$
|\mathbf{A}|=|\mathbf{U}|\left|\mathbf{\Lambda}_{\|} \mathbf{V}^{T}\right|
$$

The column vectors of $|\mathbf{U}|$ and $\mid \mathbf{V}_{\mid}$represent orthonormal bases $\mid \boldsymbol{u}_{i} \cdot, i=1, \ldots, m$ and $\mid \boldsymbol{v}_{j} \cdot, j=1, \ldots, n$ for the tracer (here tracer change) and parameter (here parameter change) spaces, respectively, associated with the model matrix $|\mathbf{A}|$. The diagonal rectangular matrix

$$
\mid \boldsymbol{\Lambda}_{\mid}=\left(\begin{array}{cccccc}
\lambda_{1} & 0 & . & . & . & 0 \\
0 & \lambda_{2} & . & . & . & . \\
. & . & . & . & . & . \\
. & . & . & . & . & . \\
. & . & . & . & . & . \\
. & . & . & . & . & 0 \\
0 & . & . & . & 0 & \lambda_{n} \\
0 & . & . & . & . & 0 \\
. & . & . & . & . & . \\
0_{1, m} & . & . & . & . & 0_{n, m}
\end{array}\right)
$$

consists of the singular values $\lambda_{k}$. The eigenvectors $\mid u_{k}$, । $v_{k} \cdot$ and the eigenvalues $\lambda_{k}$ form the solution of the coupled eigenvalue problem

$$
\left|\mathbf{A}_{\|} \boldsymbol{v}_{k} \cdot=\lambda_{k}\right| \boldsymbol{u}_{k},
$$

$\mathbf{A}^{T} \| \boldsymbol{u}_{k} \cdot=\lambda_{k} \mid \boldsymbol{v}_{k} \cdot$

with the following properties:

$$
\begin{aligned}
\mid \mathbf{A}_{\|} \mathbf{A}^{T} \| \boldsymbol{u}_{k} \cdot & =\lambda_{k}^{2} \mid \boldsymbol{u}_{k} \cdot \\
\mid \mathbf{A}^{T} \| \mathbf{A}_{\|} \boldsymbol{v}_{k} \cdot & =\lambda_{k}^{2} \boldsymbol{v}_{k} \cdot
\end{aligned}
$$

The number $\quad p \leq \min (m, n)$ of non-zero singular values defines the rank of $|\mathbf{A}|$. The unknown parameter changes $\mid \hat{\boldsymbol{x}}$. and the modelled tracer changes $\mid \hat{\boldsymbol{g}}$. can now be written in terms of the linearly independent eigenvectors $\mid \boldsymbol{v}_{j} \cdot$ and $\mid \boldsymbol{u}_{i} \cdot$, respectively:

$$
\begin{aligned}
& \mid \hat{\boldsymbol{x}} \cdot=\left(\hat{x}_{1}, \ldots, \hat{x}_{n}\right)=\sum_{j=1}^{p=n<m} \alpha_{j} \boldsymbol{v}_{j}, \\
& \left|\hat{\boldsymbol{g}} \cdot=\left(\hat{g}_{1}, \ldots, \hat{g}_{m}\right)=\sum_{i=1}^{p=n<m} \beta_{i}\right| \boldsymbol{u}_{i},
\end{aligned}
$$

where the $\alpha_{j}$ are unknown and $\beta_{i}=\cdot \boldsymbol{u}_{i}^{T} \| \boldsymbol{g} \cdot$. The observed tracer changes are correspondingly given by $\mid \boldsymbol{g} \cdot \equiv$ $\sum_{i=1}^{m} \beta_{i} \mid \boldsymbol{u}_{i} \cdot$ Equations (4), (7), and (9) together yield the solution for the optimal parameter changes:

$\hat{\boldsymbol{x}} \cdot=\sum_{j=1}^{n} \alpha_{j}\left|\boldsymbol{v}_{j} \cdot=\sum_{i=1}^{n} \frac{1}{\lambda_{i}}{ }_{\boldsymbol{v}} \cdot \boldsymbol{u}_{i}^{T}\right| \mid \boldsymbol{g} \cdot$

with $\alpha_{i}=\beta_{i} / \lambda_{i}$. Because only $p=n<m$ vectors $\mid \boldsymbol{u}_{i} \cdot$ are combined in the overdetermined case, residuals between modelled tracer changes $\mid \hat{\boldsymbol{g}}$. and observed tracer changes $\mid \boldsymbol{g}$. occur. Thus, the observed tracer variations cannot be completely recombined by the least-squares solution of Eq. (12).

In the exactly determined case we would have

$|\hat{\boldsymbol{g}} \cdot \equiv| \boldsymbol{g} \cdot=\sum_{i=1}^{m} \beta_{i}\left|\boldsymbol{u}_{i} \cdot=\sum_{i=1}^{m}\right| \boldsymbol{u}_{i} \cdot \boldsymbol{u}_{i}^{T}|| \boldsymbol{g} \cdot=\left|\left(\boldsymbol{\delta}_{i j}\right)\right| \mid \boldsymbol{g} \cdot$

where $\delta_{i j}=\left\{\begin{array}{l}1 \text { for } i=j \\ 0 \text { for } i \neq j\end{array}\right.$.

For the overdetermined case we arrive at

$$
\begin{aligned}
\mid \hat{\boldsymbol{g}} & =\sum_{i=1}^{p=n<m} \beta_{i}\left|\boldsymbol{u}_{i} \cdot=\sum_{i=1}^{p=n<m}\right| \boldsymbol{u}_{i} \cdot \boldsymbol{u}_{i}^{T}|| \boldsymbol{g} . \\
& =\left|\hat{\mathbf{U}}_{\|} \hat{\mathbf{U}}^{T} \| \boldsymbol{g} \cdot=\right| \mathbf{R}_{I}|| \boldsymbol{g} \cdot
\end{aligned}
$$

with $\left|\mathbf{R}_{I}\right|=\left|\hat{\mathbf{U}}_{\|} \hat{\mathbf{U}}^{T}\right|$ being the "resolution matrix" (Wiggins, 1972; Wunsch, 1989) of the changes in the tracer concentrations and $\mid \hat{\mathbf{U}}_{\mid}=\left(\left|\boldsymbol{u}_{1} \cdot, \ldots,\right| \boldsymbol{u}_{n} \cdot\right)$ the truncated "model" version of the tracer base matrix $|\mathbf{U}|$.

According to Eq. (12), the coefficient $\alpha_{i}$ in the linear combination of the parameter space eigenvectors $\mid \boldsymbol{v}_{\boldsymbol{i}} \cdot$ grows to very large values if $\lambda_{i}$ becomes very small. These very small $\lambda_{i}$ values lead to an unstable solution: only unreasonably large changes in selected parameters would be able to create the tracer changes as observed. The contributions to the solution from these small eigenvalues should be filtered out accordingly or considered with a significantly reduced weight.

For the resulting parameter changes from our fitting procedure, we discarded those components in Eq. (12) associated with the smallest singular values step by step starting with the smallest singular value, followed by the next smallest one, and so on to filter out unrealistically large parameter changes. The associated approximate solution then becomes

$\hat{\boldsymbol{x}} \cdot=\sum_{i=1}^{p<n} \frac{1}{\lambda_{i}} \boldsymbol{v}_{i} \cdot \boldsymbol{u}_{i}^{T} \| \boldsymbol{g} \cdot$ 
The number $p$ of eigenvalues retained is called the effective rank of $|\mathbf{A}|$. In our case here the full rank solution would be achieved for rank $=8$ (including all parameter changes). For an effective rank smaller than $\min (m, n)$, the formally overdetermined problem is now changed into an underdetermined problem. Nevertheless, solution Eq. (15) is the unique least-squares solution with minimum length of the solution vector for the underdetermined case (e.g. Matsu'ura and Hirata, 1982). Such a solution with minimum overall change in the system under investigation is often physically or chemically seen to be the most appropriate solution ("Occam's razor").

Because the filtered solution relies on fewer fitted parameter changes, the goodness of fit of this filtered solution is poorer than in the full rank SVD solution. Because the rank $p$ of the reduced matrix is smaller than the number of original parameters, the fitted parameters are no longer linearly independent. Now, one can specify only $p$ linearly independent parameter combinations. The full rank solution $(p=n \leq m)$ would be

$$
\begin{aligned}
\mid \hat{\boldsymbol{x}}_{\text {full rank }} \cdot & =\sum_{j=1}^{p=n} \alpha_{j}\left|\boldsymbol{v}_{j} \cdot=\sum_{j=1}^{p=n}\right| \boldsymbol{v}_{j} \cdot \boldsymbol{v}_{j}^{T} \| \hat{\boldsymbol{x}}_{\text {full rank }} \cdot \\
& =\left|\left(\boldsymbol{\delta}_{i j}\right)\right| \hat{\boldsymbol{x}}_{\text {full rank }} \cdot
\end{aligned}
$$

The solution for the rank deficient case $(p<n \leq m)$ is now

$$
\begin{aligned}
& \left|\hat{\boldsymbol{x}} \cdot=\sum_{j=1}^{p<n} \alpha_{j}\right| \boldsymbol{v}_{j} \cdot=\sum_{j=1}^{p<n} \mid \boldsymbol{v}_{j} \cdot \boldsymbol{v}_{j}^{T} \| \hat{\boldsymbol{x}}_{\text {full rank }} .
\end{aligned}
$$

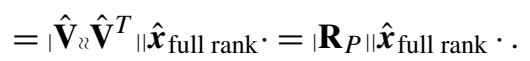

$\left|\mathbf{R}_{P \mid}=\hat{\mathbf{V}}_{2}, \hat{\mathbf{V}}^{T}\right|$ is the "resolution matrix" of the parameters with $\mid \hat{\mathbf{V}}_{2}=\left(\left|\boldsymbol{v}_{1} \cdot, \ldots,\right| \boldsymbol{v}_{p} \cdot\right)$. This resolution matrix $\mid \mathbf{R}_{P \mid}$ projects the full (in part insufficiently constrained) set of parameters onto the sub-space of stable solutions for the parameter changes. If for fixed $i$ the diagonal element $R_{i i}^{P}$ of the matrix $\mid \mathbf{R}_{P \mid}$ is close to 1 and the other elements $R_{i j}^{P}, j \neq i$ are close to zero, parameter $x_{i}$ is still well resolved even in the underdetermined case. Less well resolved parameters are instead replaced by a stable linear combination of the original parameters. Through analysis of the resolution matrix for the parameters, we can therefore determine which parameter changes can be uniquely determined by the analysis and for which parameters no clear conclusion can be made.

\section{Results and discussion}

We carried out numerous runs with the linear response model, testing different combinations of parameters and using different observed time series from palaeoclimate records as constraints. Overall, we experienced that the palaeoclimatic information and the system sensitivity as provided by the biogeochemical ocean model lead to quite consistent results if several parameters and palaeoclimatic tracers are taken into account.

We present results where all parameter changes and all palaeoclimatic tracer curves were included (see summaries in Table 5 and Figs. 6-8). The eight unknowns (namely the excursions of the parameter amplitudes relative to interglacial conditions) were determined by an optimal fit to the 20540 data points from the observational records. Formally, such a system is heavily overdetermined. No a priori knowledge and no artificial limits were imposed to the free parameters to be determined. Are the results for the free parameters reasonable? Figure 6 shows the parameter time series for the full rank solution (compare to the first-guess values as shown in Fig. 3), which also gives the best fit to the observations. Note that the model parameter changes (due to our purposeful choice) show the same temporal pattern (special case dust as discussed above) and only the maximum amplitude of the parameters was determined. The a posteriori parameter changes remain relatively close to the initially chosen parameter changes (first guesses), but with one exception. The rain ratio change shows a dramatic decrease in pelagic $\mathrm{CaCO}_{3}$ production. Such a change may not be fully out of scope (see, e.g., the discussion in Broecker and Peng, 1986, and Berger and Keir, 1984). Archer and Maier-Reimer (1994) argued that enhanced $\mathrm{CaCO}_{3}$ dissolution on the seafloor through organic carbon degradation in combination with a rain ratio reduction would provide an efficient way to reduce atmospheric $p \mathrm{CO}_{2}$. The rain ratio change itself could be provided by an increased surface ocean concentration of silicic acid by which diatoms would dominate over $\mathrm{CaCO}_{3}$ shell material production. Such a change in silicic acid concentration could be induced by enhanced iron fluxes to the Southern Ocean by dust, thinner opal frustules after the iron stress has been diminished, and subsequent export of "unused" silicic acid from the Southern Ocean to the rest of the world ocean ("silicic acid leakage hypothesis"; Matsumoto et al., 2002; Griffiths et al., 2013). Furthermore, it has been argued that low seawater temperatures lead to lower water column remineralisation rates for organic carbon and changes in the ecosystem community structure that would imply a rain ratio reduction (Matsumoto et al., 2007). On the other hand, in the case of a strong coupling between deep POC fluxes to $\mathrm{CaCO}_{3}$ fluxes (where $\mathrm{CaCO}_{3}$ works as ballast for downward organic carbon transport; see Klaas and Archer, 2002, and Armstrong et al., 2002), rain ratio shifts at the ocean surface would only have a minor impact on atmospheric $p \mathrm{CO}_{2}$ (Ridgwell, 2003). Further, one would rather expect an increase in $\mathrm{CaCO}_{3}$ production at low ambient $p \mathrm{CO}_{2}$ and high $\mathrm{CaCO}_{3}$ saturation (Zondervan et al., 2001; Riebesell et al., 2000). Therefore, the suggested strong change in the rain ratio may be an unstable part of the solution, where the fitting procedure needs huge changes in one (or possibly several parameters) to achieve minor changes in the palaeoclimate tracers simulated. (Nevertheless, the corresponding SVD solution is the unique solution of the system for full rank with altogether minimum de- 


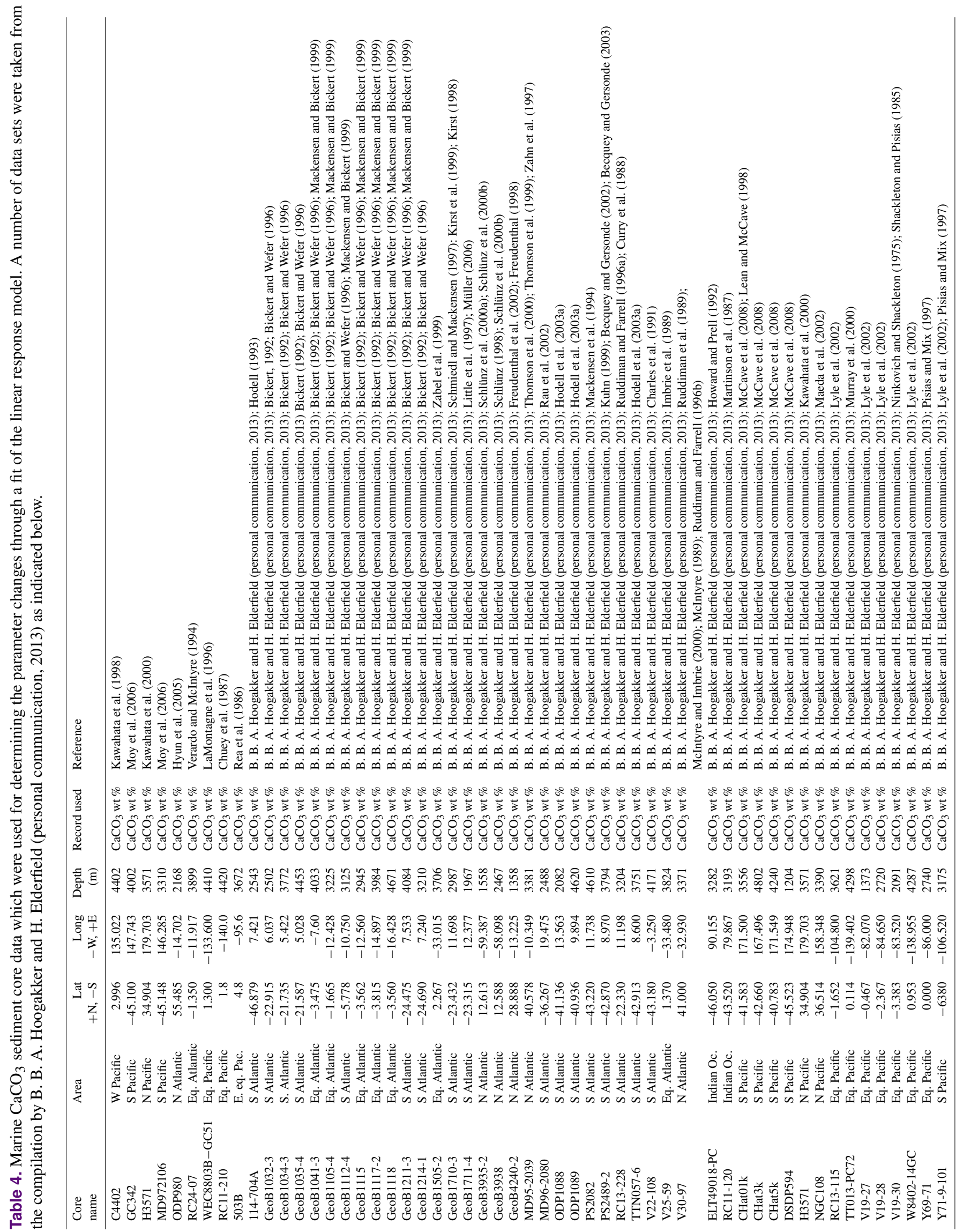


Table 5. Maximum parameter changes at the Last Glacial Maximum relative to the interglacial control run.

\begin{tabular}{|c|c|c|c|c|c|c|c|c|}
\hline Run specification & $\begin{array}{r}\mathrm{SST} \\
\left({ }^{\circ}\right)\end{array}$ & $\begin{array}{r}\text { Land C } \\
\text { storage } \\
(\mathrm{PgC})\end{array}$ & $\begin{array}{r}\text { POC } \\
\text { dissol. } \\
\text { rate } \\
(\%)\end{array}$ & $\begin{array}{r}\text { BSi } \\
\text { dissol. } \\
\text { rate } \\
(\%)\end{array}$ & $\begin{array}{r}\text { Rain } \\
\text { ratio } \\
\text { change } \\
\mathrm{CaCO} 3: \mathrm{C}_{\text {org }} \\
(\%)\end{array}$ & $\begin{array}{l}\text { Circulation } \\
\text { change } \\
\text { on } \\
(\%)\end{array}$ & $\begin{array}{r}\begin{array}{r}\text { Dust } \\
\text { change }\end{array} \\
\text { on } \\
(\%)\end{array}$ & $\begin{array}{c}\text { Carbon } \\
\text { over- } \\
\text { consumption } \\
\text { change } \\
\text { (units } \mathrm{C} \text { rel. to } \mathrm{P} \text { ) }\end{array}$ \\
\hline Full rank 8 & -6.017 & -416.7 & 5.131 & 3.047 & -34.29 & 48.21 & 7.861 & 28.32 \\
\hline Rank 7 & -7.894 & -441.7 & -1.171 & -11.85 & -7.438 & 25.88 & 9.39 & 10.51 \\
\hline Rank 6 & -4.938 & -438.3 & -0.156 & 2.373 & 1.685 & 45.95 & 12.34 & 10.50 \\
\hline
\end{tabular}

viation from the control run.) Therefore, we started to reduce the rank from 8 to first 7 and then 6 - i.e. we still aimed at determining all eight parameter changes simultaneously, but partially in linear combination with each other. In the solution for rank 7 (Fig. 7), the change in sea surface temperature seems to be unrealistically high. A global decrease by about $8^{\circ} \mathrm{C}$ would imply an unrealistic widespread ocean freezing. The solution for rank 6 (Fig. 8) finally arrives at overall realistic parameter excursions during the past climatic cycle. For maximum changes at the LGM, our analysis arrives at

- a maximum decrease in global sea surface temperature by $5^{\circ}$,

- a decrease in the land biosphere by $430 \mathrm{Pg} \mathrm{C}$,

- only minor changes in POC and BSi degradation,

- a suggested change in the ocean velocities towards glacial conditions (no full switch, however),

- only a small effect from dust deposition,

- and a sizable strengthening of the biological organic carbon pump through a stoichiometry change.

The resulting requirement for a strengthening of the biological pump could potentially also be due to other processes than a stoichiometry change in reality.

The suggested glacial drop in average SST by $5{ }^{\circ} \mathrm{C}$ may still be overestimated. Originally, CLIMAP Project Members (1976) and Broecker (1986) estimated a glacial-interglacial change of only ca. -2.0 to $-2.3{ }^{\circ} \mathrm{C}$ from faunal assemblages and oxygen isotopes, with the more recent quantification by MARGO Project Members (2009) being at the lower end of this range. Other estimates suggest a decline in the SST of $5.4^{\circ} \mathrm{C}$ (Stute et al., 1995) and even $6.5^{\circ} \mathrm{C}$ (Weyhenmeyer et al., 2000). Green et al. (2002) arrive at an estimate for tropical SST glacial decrease of around $3{ }^{\circ} \mathrm{C}$ but give a range of studies (see their Table 2 on pp. 4-9 in Greene et al., 2002). Our study confirms the order of magnitude in this parameter, using an independent approach.

A decrease in land vegetation due to colder and drier climate conditions at the LGM relative to pre-industrial

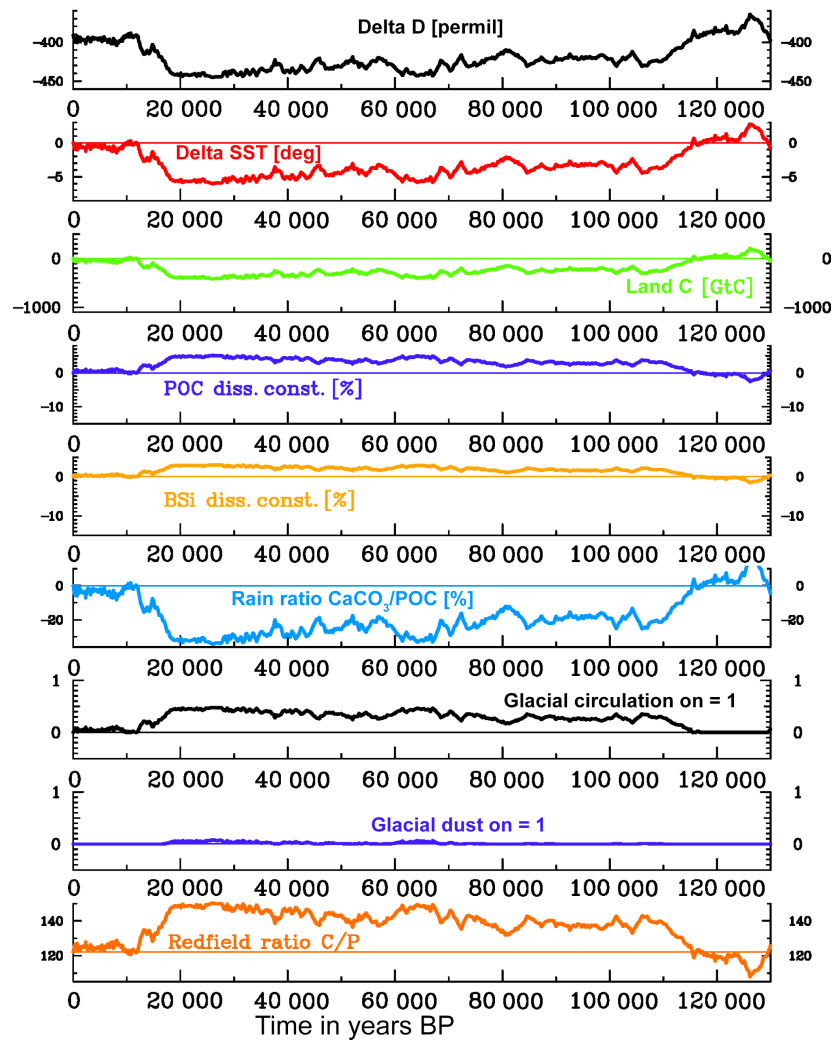

Figure 6. Resulting parameter variations in the past climatic cycle for the full rank solution of the linear response model.

conditions has been estimated by several authors employing various approaches: $430 \mathrm{Pg} \mathrm{C}$ (Shackleton, 1977), 530$1160 \mathrm{Pg} \mathrm{C}$ (Crowley, 1995), $330 \mathrm{Pg} \mathrm{C}$ (Ciais et al., 2012), and $597 \mathrm{Pg} \mathrm{C}$ (O'ishi and Abe-Ouchi, 2013). Interestingly, our estimate is closest to the value originally determined by Shackleton (1977), which may be due to the marine $\delta^{13} \mathrm{C}$ constraint used in that study and which is also included in our analysis. Overall, our study confirms earlier estimates on the LGM terrestrial through our independent approach.

Our fitting procedure confirms that the glacial ocean circulation should have somehow resembled the simulated glacial ocean conditions as deduced by Winguth et al. (1999). However, in an ideal case with a perfect simulation of the glacial 


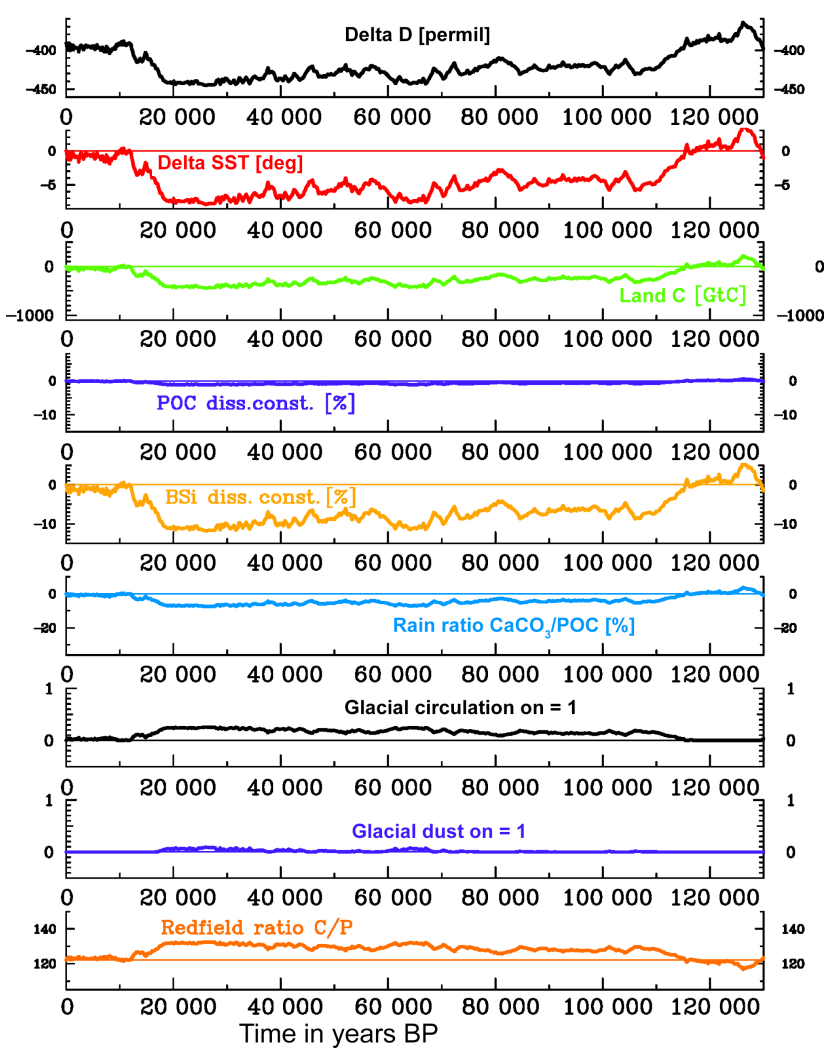

Figure 7. Resulting parameter variations in the past climatic cycle for the rank 7 solution of the linear response model.

ocean circulation, the switch to this circulation at glacial conditions should be close to $100 \%$ and not only the $50 \%$ seen in this study. This may still be due to some deviations of the simulated glacial ocean velocity especially for the Pacific Ocean, but possibly also due to deficiencies in the biogeochemical model, including its sediment module. Nevertheless, the tendency of a reaction towards glacial physical boundary conditions resulting from the fitting procedure is encouraging and consistent. Ideally, one would need to simulate the glacial ocean circulation in a coupled Earth system model including an ice sheet model over the entire last glacial-interglacial climatic cycle. However, even given the availability of such a detailed and realistic velocity, the computing times for carrying out the various sensitivity experiments would be prohibitively large due to the required short time step in such simulations. Nevertheless, in future studies it would be desirable to also include quick alterations of the ocean velocity field, especially changes in ocean overturning. Such short-term climatic changes (centennial to millennial timescales) have been inferred from ice core as well as sediment core analysis, known as Dansgaard-Oeschger events (Dansgaard et al., 1993, Anklin et al., 1993), where the coldest events are also marked by large amounts of ice-rafted debris in sediment cores (Heinrich events, Bond et al., 1993). Non-linear ocean-atmosphere dynamics (Barker et al., 2015;

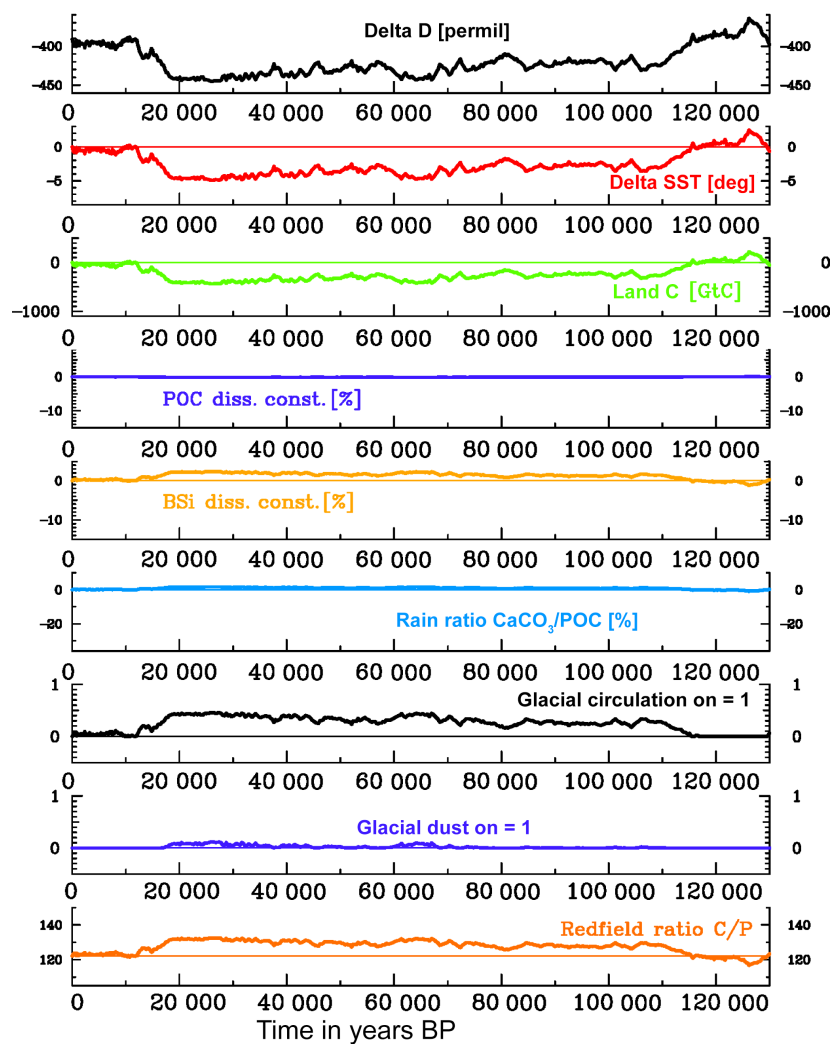

Figure 8. Resulting parameter variations in the past climatic cycle for the rank 6 solution of the linear response model.

Olsen et al., 2005) would need to be included in respective simulation attempts. Also, the representation of sea water temperature changes can be improved. The LGM sea surface temperatures have been accounted for through the respective glacial forcing field underlying the simulation (CLIMAP Project Members, 1976; CLIMAP Project Members, 1981). The simulated deep-water temperature drop below $1500 \mathrm{~m}$ was around $1.2^{\circ} \mathrm{C}$ on the average (Winguth et al., 1999) as compared to the pre-industrial/interglacial simulation, with some areas where the temperature difference was up to $-2{ }^{\circ} \mathrm{C}$, especially in the North Atlantic deep water. Reconstructions of bottom water temperatures through oxygen isotope pore water analysis revealed a temperature decrease of around $2{ }^{\circ} \mathrm{C}$ at the Carnegie Ridge (Pacific) and the Ceara Rise (Atlantic) (Cutler et al., 2003) and, close to deep-water production sites, cooling of deep waters in the North Atlantic, South Pacific, and Southern Ocean by about 4-5, 2.5, and $1.5^{\circ} \mathrm{C}$ (Adkins et al., 2002). Consistent with this, bottom water interglacial-glacial temperature changes have been inferred from $\mathrm{Mg} / \mathrm{Ca}$ palaeo-thermometry (Dwyer et al., 1995, Skinner et al., 2003, Roberts et al., 2016). The modelled sea water temperatures may thus be somewhat higher than the observed ones, especially for the Southern Ocean. It should be note that the circulation change experiment with the biogeochemical model was carried out with pre-industrial 
(a)

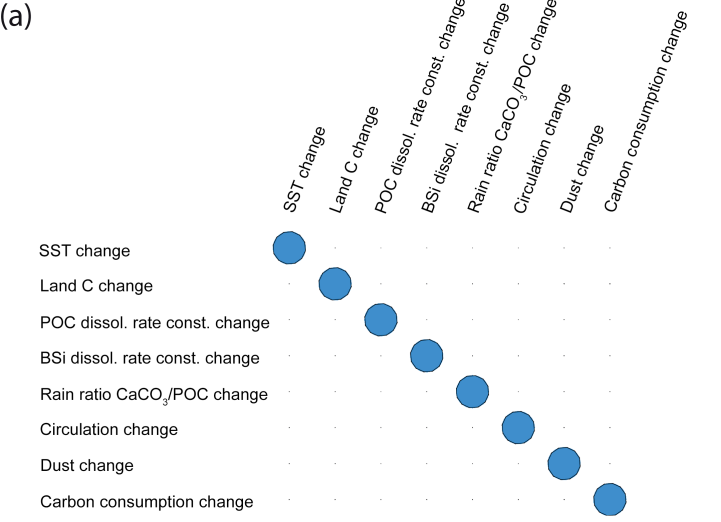

(b)

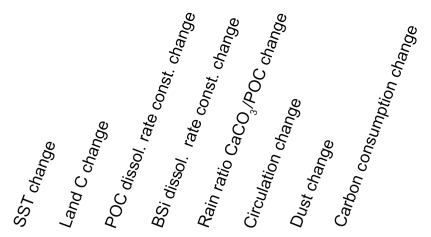

\section{SST change}

$$
\text { Land } \mathrm{C} \text { change }
$$

POC dissol. rate const. change BSi dissol. rate const. change Rain ratio $\mathrm{CaCO}_{3} / \mathrm{POC}$ change . Circulation change Dust change Carbon consumption change

(c)
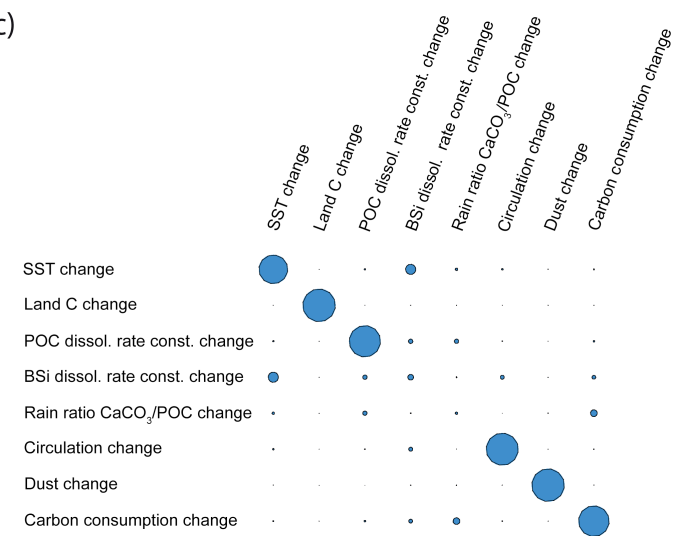

Figure 9. Resolution matrices for the full rank (rank 8) (a), rank 7 (b), and rank 6 (c) solutions. The $\mathrm{CaCO}_{3}: \mathrm{C}_{\text {org }}$ rain ratio variations can no longer determined for a realistic length of the solution vector of parameter variations.

temperatures (for the biogeochemistry only) in order to separate the temperature and circulation effects properly (and to avoid linear parameter dependencies in the inverse approach). The most difficult aspects to interpret in the results are the reactions of the ecosystem parameters. The small changes in POC and BSi degradation or dissolution rates may be realistic in view of the overall still modest change in seawater temperatures. The almost vanishing rain ratio change in the rank 6 solution and the suggested rain ratio decrease (a)

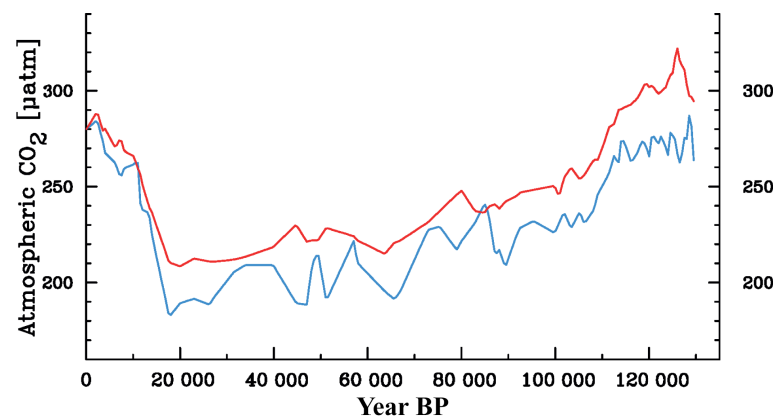

(b)

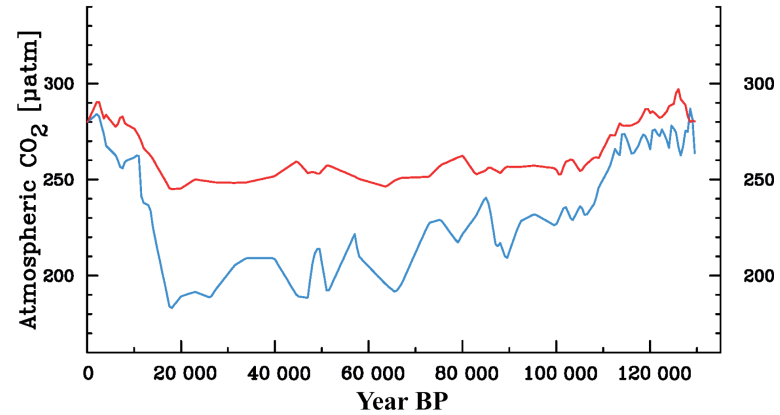

(c)

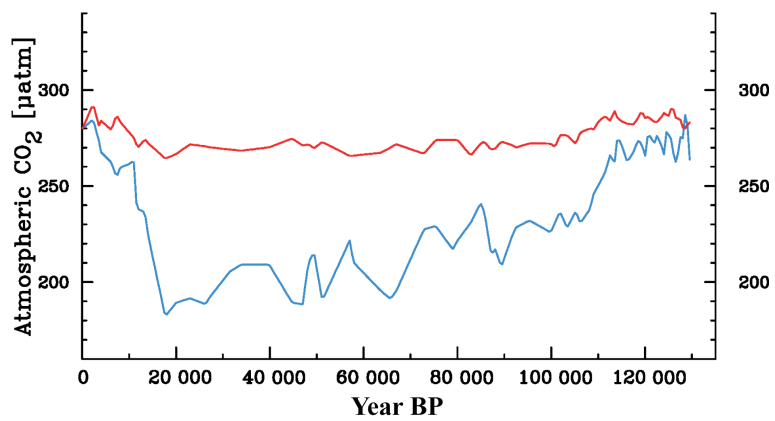

Figure 10. Goodness of fit for the full rank (rank 8) (a), rank 7 (b), and rank 6 (c) solutions (blue line: observations; red line: inverse modelling result). The example is for the predicted evolution of atmospheric $\mathrm{CO}_{2}$. The observed record comes from the Vostok ice core, Antarctica (Barnola et al., 1987). The rendering of realistic parameter variations in the rank deficient solutions is accompanied by a strong reduction in goodness of fit.

(corresponding to $\mathrm{CaCO}_{3}$ export production decrease) cannot be easily explained. The lack of better information on $\mathrm{CaCO}_{3}$ production during glacial times does not allow us to give any clear answer concerning potential ocean acidification impacts. The reaction of the system during glacial times remains diffuse in our analysis (see also below for the resolution of parameters analysis).

For some $\mathrm{CaCO}_{3}$ tracer records a remarkable improvement in fit resulted when increased dust deposition and the related dilution effect were employed (not shown). However, on average the inverse approach does not suggest a strong effect of the dust deposition changes for providing a better reproduction of the palaeoclimate tracers here. This can possibly be due to the simple modelling approach which we take here and to the regional variations in dust deposition which so far cannot be resolved by the input fields. 


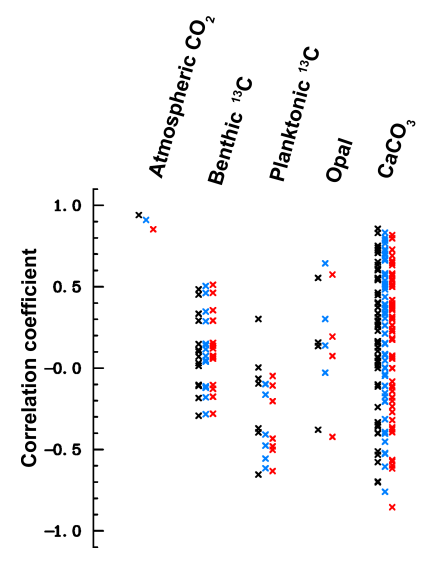

Figure 11. Correlation coefficients between observations and predicted tracer values from the linear response model. The correlation coefficients are shown from left to right for the various tracer types. Each record is represented by one small cross. Values for the full rank solution are given in black, values for rank 7 in blue, and values for rank 6 in red.

The increase in carbon overconsumption (change in stoichiometry of carbon to nutrient elements) as suggested in our study confirms earlier results (Heinze and Hasselmann, 1993). This does not necessarily mean that such a change in carbon-to-nutrient ratio is realistic, for two reasons: the ecosystem changes needed to achieve such a shift would have to be dramatic and the glacial-interglacial atmospheric $\mathrm{CO}_{2}$ change corresponds in amplitude to the change between the pre-industrial period and the early 21 st century. So far, no respective carbon underconsumption due to the anthropogenic $\mathrm{CO}_{2}$ release has been identified. Rather, the opposite has been suggested for further dramatic increases in atmospheric and sea surface $\mathrm{CO}_{2}$ (Riebesell et al., 2007). The increase in carbon-to-nutrient ratios under cold and low- $\mathrm{CO}_{2}$ conditions would contradict the evidence from mesocosm experiments in a Norwegian coastal setting (Riebesell et al., 2007). The experimental results from the mesocosm studies may potentially be influenced by the specific experiment setting and thus may not be valid at other locations. Earlier, Heinze and Hasselmann (1993) were not able to properly separate the effect of the stimulation of POC export production by a change in stoichiometry or by an increase in the oceanic inventory of dissolved phosphate. Thus, the requirement of a carbon overconsumption in this study may indicate that the biological organic carbon production may have been stimulated by other processes such as fertilisation of ocean productivity by dust-derived micro-nutrients.

We also look at the impact of the rank reduction on the parameter change quantification and the goodness of fit to the observations. The reduction in the rank of our linear system means that not all unknown parameter changes can be determined in an independent way. The resolution matrix of the parameters (see Eq. 17) identifies which free parameters can still be uniquely determined after the rank reduction and which ones can only be given as linear combinations of each other.

Instead of giving the matrices in terms of numerical values, we visualised the matrices through the use of circles in Fig. 9, for the solution with rank 8 (full rank), rank 7, and rank 6 . The full rank resolution diagram shows a perfect diagonal with all parameters formally perfectly resolved. For the rank reduction, the resolution for the rain ratio change, as well as the BSi dissolution rate change, deteriorates strongly. This shows that the linear system is in fact poorly constrained, and that very little can be firmly stated about the glacial-interglacial rain ratio change. Unfortunately, implications for future ocean acidification impacts cannot be deduced from our analysis. This is important information, however. It may be that the quite comprehensive sediment record collection which we employed here may still be inadequate to address the ocean acidification problem and possibly also the atmospheric glacial $\mathrm{CO}_{2}$ drawdown problem. Parts of the real system may not be represented - be it in the observations, in the model, or both. Further sedimentary tracer types may be needed in order to make the database more complete and to resolve all (and possibly more) carbon cycle parameters properly. The trade-off between realistic parameter estimates and goodness of fit becomes obvious when one checks, for example, the overall estimated reproduction of the atmospheric Vostok ice core curve for the full rank and rank deficient solutions (Fig. 10). While the full rank solution gives a quite striking fit to the atmospheric $\mathrm{CO}_{2}$ curve, there is already a strong decrease in fit in the rank 7 solution, while finally the rank 6 solution (and thus also all solutions with smaller ranks) reveals an almost complete deterioration of the fit. This provides a clear dilemma. In general, the improvement of the fit for a simultaneous optimisation of all parameters is quite weak except for atmospheric $p \mathrm{CO}_{2}$ (see summary in Table 6). However, our 3-D biogeochemical ocean model is not detailed enough to capture all aspects of the glacial ocean correctly. For example, our representation of the circulation variations is simplified. Also, it may be possible that we have missed one or more key processes, which may have caused or contributed to the simultaneous changes in the palaeoclimate tracer distributions. Further, we did not carry out any regional differentiation concerning the perturbation of governing parameters but used global mean changes. More detailed data assimilation schemes and the use of higher-resolution coupled biogeochemical-physical models will be an option for the future for better reproduction of the sediment core data. The price for this will be the many more degrees of freedom that need to be constrained correctly. It remains a possibility that the glacial biological $\mathrm{CaCO}_{3}$ shell material production was indeed considerably smaller than the interglacial production, such that this parameter change did not cause any major imprint on the palaeoclimate tracer combination used in this study. In addition, some of the sedimentary records may also reflect specific local 
conditions which cannot be spatially resolved by our coarse model. Such special local conditions may include sediment focusing due to specific bathymetric features, smaller-scale dynamic flow conditions such as localised upwellings, and meandering frontal systems.

We also analysed the change in simulated tracer records as compared to the control run (Table 7). As one can see, in spite of the poor fit (except for the atmospheric $p \mathrm{CO}_{2}$ record), deviations from the tracer output records of the model control run occurred. These tend to get smaller with the reduction in the rank. Correlation coefficients between observations and predicted tracer values from the linear response model are given in Fig. 11. While for a series of single records the correlation is good, for other single records the correlation is poor or even anticorrelations resulted. This is especially the case for the planktonic $\delta^{13} \mathrm{C}_{\text {planktonic }}$ records. This deficiency can be in part explained through the coarse model resolution. If the regional extent of upwelling zones is different between model and reality, the respective surface tracers for palaeoproductivity as recorded in the sediment cores will also show respective differences.

In previous studies on the glacial-interglacial changes in the ocean carbon cycle, often hypotheses involving one specific mechanism were presented or the multitude of potential mechanisms was reviewed. Studies where the simultaneous contributions from several processes to glacial carbon dynamics have been discussed are relatively scarce. Brovkin et al. (2007) employed an Earth system model of intermediate complexity including oceanic and terrestrial biogeochemical modules to test the impact of simultaneous changes on the atmospheric $\mathrm{CO}_{2}$ concentration. Their results are fairly consistent with those of this study. According to Brovkin et al. (2007), largest contributions to the $\mathrm{CO}_{2}$ drawdown came from circulation and SST changes as well as from a strengthening of the biological pump through improved nutrient utilisation, while the land outgassing amounted to an atmospheric $p \mathrm{CO}_{2}$ increase by $15 \mathrm{ppm}$. Rain ratio changes contributed to about $15 \mathrm{ppm}$, a process also mentioned as a less certain mechanism by Brovkin et al. (2007). In addition, they report secondary changes of atmospheric $p \mathrm{CO}_{2}$ due to weathering, sea level change, and changes in sedimentation (shallow water vs. deep water).

Recent studies have again focused on the mineral dust hypothesis involving increased iron supply especially to the Southern Ocean (originally revived by Martin et al., 1994, and Berger and Wefer, 1991) and a respective regional strengthening of biological production and carbon export. Increased LGM aerosol iron flux to the Southern Ocean could be corroborated by Conway et al. (2015). With our approach, in a separate experiment (not shown in this study, where we only consider dust for solution of sedimentary material) we also had tested increased ocean productivity and related surface nutrient drawdown due to changing dust deposition. The inverse approach did not favour this process. This is fairly consistent with the modelling study by Lambert et al. (2015) arriving at a direct effect of the iron-induced biological pump strengthening of less than $10 \mathrm{ppm}$ and the delayed effect due to carbon burial and carbonate compensation by about $10 \mathrm{ppm}$.

Inspired by the suggestion of temperature-dependent export production of Laws et al. (2000), Matsumoto et al. (2007) quantify, in a further single mechanism study, the effect of temperature-dependent remineralisation on the atmospheric $\mathrm{CO}_{2}$ using an ocean biogeochemical model. According to their findings, an LGM atmospheric $\mathrm{CO}_{2}$ decline by $30 \mathrm{ppm}$ would be possible through this process. In our study, the parameter change in the POC remineralisation rate with temperature forcing did not result in a similarly likely drawdown when tested in the inverse approach against evidence from the sedimentary record. Rather, our work suggests that simple temperature- and $p \mathrm{CO}_{2}$-dependent changes in ocean physics as well as biogeochemistry do not straightforwardly translate into atmospheric $\mathrm{CO}_{2}$ changes and respective sedimentary imprints, but that the problem is more complicated.

The Southern Ocean has been established to be one of the key regions for regulating glacial-interglacial carbon dynamics. Apart from processes involving dissolved iron and nutrients, especially the physical dynamical processes - and hence stratification, deep-water production, upwelling, water mass formation, and lateral advection - have been considered in conjunction with the physical/chemical and biological carbon pumps. Special emphasis has been placed on a northward shift of the westerly wind forcing at the LGM as compared to today (Toggweiler et al., 2006; Watson and Garabato, 2006; Watson et al., 2015). The general idea is that a northward shift of Southern Ocean upwelling leads to reduced $\mathrm{CO}_{2}$ outgassing and enhanced carbon export to the deep waters, resulting in a deep ocean accumulation of organic matter from the surface and hence a vertical "fractionation" of carbon as well as nutrients as already described by Boyle (1988a) and Boyle (1988b). This general view is also corroborated by recent proxy data findings (for the Southern Ocean by Gottschalk et al., 2016; also for the North Atlantic by Hoogakker et al., 2015). Refined Southern Ocean dynamics could also improve the results of our studies, but we have been limited to the flow fields available. In general, Southern Ocean flow field and tracer simulations traditionally show a large intermodel spread (Broecker et al., 1998; Roy et al., 2011; Orr, 2002). One of the reasons is the complex interplay of sea ice as well as wind forcing and also the subgridscale parameterisation of convection events which occur on narrow regional scales in reality (Gordon, 1978). Still, simulating the Southern Ocean flow field and mixing remains a key challenge even for the modern ocean (Farneti et al., 2015: Downes et al., 2015; Mignot et al., 2013; Abernathey et al., 2016). 
Table 6. Average goodness of fit expressed as root mean square error for the control run base line and the different optimisations. The values for the optimisations are estimated from the linear fitting procedure.

\begin{tabular}{lcccccc}
\hline Run specification & $\begin{array}{c}\mathrm{All} \\
\text { records } \\
\text { (normalised } \\
\text { units) }\end{array}$ & $\begin{array}{c}\text { Atmosph. } \\
\mathrm{CO}_{2} \\
(\mathrm{ppm})\end{array}$ & $\begin{array}{c}\delta^{13} \mathrm{C} \\
\text { benthic } \\
(\% \circ)\end{array}$ & $\begin{array}{c}\delta^{13} \mathrm{C} \\
\text { planktonic } \\
(\% o)\end{array}$ & $\begin{array}{c}\mathrm{BSi} \\
(\text { wt \%) }\end{array}$ & $\begin{array}{c}\mathrm{CaCO}_{3} \\
(\text { wt \%) }\end{array}$ \\
\hline Control run & 0.4636 & 61.02 & 0.3515 & 0.5515 & 4.454 & 15.10 \\
Full rank 8 & 0.3519 & 21.05 & 0.2443 & 0.4507 & 4.059 & 14.39 \\
Rank 7 & 0.3559 & 38.59 & 0.2452 & 0.4804 & 3.982 & 14.66 \\
Rank 6 & 0.3580 & 53.25 & 0.2446 & 0.4782 & 4.052 & 14.94 \\
\hline
\end{tabular}

Table 7. Average root mean square deviation of the optimised modelled tracer records (as estimated from the simultaneous fit of the sensitivity experiment results to the observations) from the simulated control run tracer record. A zero value would mean that no difference with respect to the control run has occurred. The larger the values, the more the optimised tracer curves and the control run tracer curves differ (a value of zero would mean that there is no change between the result from the fitting procedure and the control run).

\begin{tabular}{lccccc}
\hline Run specification & $\begin{array}{c}\text { Atmosph. } \\
\mathrm{CO}_{2} \\
(\mathrm{ppm})\end{array}$ & $\begin{array}{c}\delta^{13} \mathrm{C} \\
\text { benthic } \\
(\% \circ)\end{array}$ & $\begin{array}{c}\delta^{13} \mathrm{C} \\
\text { planktonic } \\
(\% \circ)\end{array}$ & $\begin{array}{c}\mathrm{BSi} \\
(\text { wt \%) }\end{array}$ & $\begin{array}{c}\mathrm{CaCO}_{3} \\
(\text { wt \%) }\end{array}$ \\
\hline Full rank 8 & 46.12 & 0.2471 & 0.3514 & 1.497 & 6.062 \\
Rank 7 & 23.49 & 0.2465 & 0.3831 & 1.090 & 4.752 \\
Rank 6 & 8.887 & 0.2480 & 0.3595 & 1.070 & 3.554 \\
\hline
\end{tabular}

\section{Conclusions}

In our study we combine a comprehensive sedimentary database from the palaeoclimatic sediment core record with a coarse-resolution BOGCM. We assume that the governing carbon cycle parameter variations over the past climatic cycle follow the same temporal pattern. As the palaeo-record of atmospheric $p \mathrm{CO}_{2}$ and surface temperature show a strong correlation (Siegenthaler et al., 2005), we cannot decide in general whether the parameter variations are caused by physical forcing (temperature), chemical forcing $\left(\mathrm{CO}_{2}\right)$, or both simultaneously. With such approximation, we can reduce the search for unknown parameter changes to the maximum amplitude of these changes at the LGM. By employing 79 observed palaeoclimatic tracer data curves (with altogether 20540 formal data points) for determination of eight unknown maximum parameter excursions with respect to the pre-industrial situation, we arrive at a formally completely overdetermined linear response model for estimating the parameter changes. We can confirm the quantification for mean global maximum SST change $(-5 \mathrm{~K})$ and carbon loss from terrestrial systems $(-430 \mathrm{Pg} \mathrm{C})$ to the atmosphere as suggested by earlier studies. Further, our model-data combination clearly identifies a substantial increase in the biological organic carbon export during glacial times, though the underlying process may not be a carbon-to-nutrient overconsumption. The response of glacial-interglacial changes in the biological $\mathrm{CaCO}_{3}$ production remain uncertain. $\mathrm{CaCO}_{3}: \mathrm{C}_{\text {org }}$ rain ratio reductions may have contributed to the glacial $\mathrm{CO}_{2}$ reduction in the atmosphere, but such rain ratio changes cannot be resolved with our linear response model. This may be due to model deficiencies in our approach, or due to lack of information from the present database for this purpose. With our combination of model results and observations, no overall answer concerning the mechanisms behind the glacial $p \mathrm{CO}_{2}$ drawdown can be provided. Simple synchronous temperature-dependent or atmospheric $p \mathrm{CO}_{2}-$ dependent forcing fields and governing parameter time series of the same temporal pattern appear to not be able to reproduce the marine sediment core record satisfactorily. 


\section{Appendix A: Model details}

Major process parameterisations of the biogeochemical model used in this study are summarised below. The model is the annually averaged version of the HAMOCC model (Maier-Reimer, 1993; Maier-Reimer et al., 2005) and has been described elsewhere (Heinze and Maier-Reimer, 1999; Heinze et al., 1999; Heinze et al., 2003; Heinze et al., 2009). Several free model parameters have been tuned anew for this study as compared to earlier studies. A number of important parameters are summarised in Table A1.

\section{A1 Air-sea gas exchange}

The atmospheric model reservoir and the ocean surface layer exchange both $\mathrm{CO}_{2}$ and oxygen. The flux of $\mathrm{CO}_{2}$ across the air-sea interface is simulated as follows:

$F_{\mathrm{CO}_{2}}=k_{\mathrm{CO}_{2}} \cdot\left(p \mathrm{CO}_{2, \text { air }}-p \mathrm{CO}_{2, \text { water }}\right)$,

where $F_{\mathrm{CO}_{2}}$ is the carbon dioxide flux across air-sea interface and $k_{\mathrm{CO}_{2}}$ is the specific gas exchange rate. The $\mathrm{CO}_{2}$ partial pressure is calculated from the free carbon dioxide concentration (sum of aqueous $\mathrm{CO}_{2}$ and carbonic acid) in seawater with Henry's law through use of the solubility $\alpha$ (Weiss, 1974):

$p \mathrm{CO}_{2, \text { water }}=\alpha \cdot\left[\mathrm{CO}_{2}\right]$.

For the oxygen flux the following approach is pursued:

$F_{\mathrm{O}_{2}}=k_{\mathrm{O}_{2}} \cdot\left(C_{\mathrm{O}_{2}, \text { equilibrium }}-C_{\mathrm{O}_{2} \text {,actual }}\right)$

$C_{\mathrm{O}_{2} \text {,equilibrium }}=f(T, S) \cdot C_{\mathrm{O}_{2} \text {, atmosphere }}(t)$,

where $F_{\mathrm{O}_{2}}$ is the net gas flux between sea surface and atmosphere, $k_{\mathrm{O}_{2}}$ is the mean gas transfer velocity, $C_{\mathrm{O}_{2} \text {,equilibrium }}$

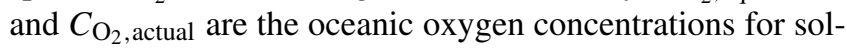
ubility equilibrium with the atmosphere and the actual observed (or modelled) value, $f(T, S)$ is the measured solubility as a function of sea water temperature and salinity, and $C_{\mathrm{O}_{2} \text {, atmosphere }}(t)$ is the tropospheric $\mathrm{O}_{2}$ concentration, where $f(T, S)$ is taken from Weiss (1970). $\mathrm{O}_{2}$ gas exchange is a result of the analytical solution of the differential equation

$\frac{\mathrm{d} C}{\mathrm{~d} t}=F / \Delta z$

where $C$ is the gas concentration in $\left[\mathrm{mol} \mathrm{cm}^{-3}\right], F$ the flux in $\left[\mathrm{mol} \mathrm{cm}{ }^{-2} \mathrm{~s}^{-1}\right]$ of gas into (or out of) a control volume of $1 \mathrm{~cm}$ length, $1 \mathrm{~cm}$ width, and thickness $\Delta z$ in [cm]. The numerical formulation is

$C^{\text {new }}=C_{\text {equilibrium }}+\left(C^{\text {old }}-C_{\text {equilibrium }}\right) \cdot e^{\left(-k_{a v} / \Delta z\right) \cdot \Delta t}$,

where $\Delta t$ is the time step (here 1 year) and $\Delta z$ is the thickness of the layer affected by gas exchange $(\Delta z$ is set equal to $50 \mathrm{~m}$ in cases of hydrostatic stability and to the maximum depth of the convective layer else). The model atmosphere is represented through a one-layer box over each grid point. At every time step, zonal averages are determined for the atmospheric concentrations. Gas transport is simulated through meridional diffusion only (as in reality the intrahemispheric tropospheric mixing time is much shorter than the time step of 1 year applied here).

\section{A2 Biogenic particle export production and particle flux through the water column}

As a consequence of the annual averaging, the model simulates only export production of biogenic particles. Particle production is assumed to exclusively take place in the model surface layer representing the euphotic zone. Phosphate serves as the ultimate biolimiting nutrient. The nitrogen cycle is not simulated explicitly. POC (particulate organic carbon) and opal export production rates are predicted using Michaelis-Menten kinetics for nutrient uptake (e.g. Parsons and Takahashi, 1973):

$$
\begin{aligned}
P_{\mathrm{POC}} & =\frac{V_{\mathrm{max}}^{\mathrm{POC}} \cdot\left[\mathrm{PO}_{4}^{3-}\right]^{2} \cdot \operatorname{Red}(\mathrm{C}: \mathrm{P})}{K_{\mathrm{s}}^{\mathrm{POC}}+\left[\mathrm{PO}_{4}^{3-}\right]}, \\
P_{\mathrm{opal}} & =\frac{V_{\mathrm{max}}^{\mathrm{opal}} \cdot\left[\mathrm{Si}(\mathrm{OH})_{4}\right]^{2}}{K_{\mathrm{s}}^{\mathrm{opal}}+\left[\mathrm{Si}(\mathrm{OH})_{4}\right]},
\end{aligned}
$$

where $P_{\mathrm{POC}}$ and $P_{\mathrm{opal}}$ are the $\mathrm{POC}$ and opal export production rates $\left[\mathrm{mol} \mathrm{L}^{-1} \mathrm{yr}^{-1}\right], \operatorname{Red}(\mathrm{C}: \mathrm{P})$ is the Redfield ratio $\mathrm{C}: \mathrm{P}, V_{\max }^{\mathrm{POC}}$ and $V_{\max }^{\mathrm{opal}}$ are the maximum uptake rate of phosphate and silicic acid from the water column $\left[\mathrm{yr}^{-1}\right]$, and $K_{\mathrm{s}}^{\mathrm{POC}}$ and $K_{\mathrm{s}}^{\mathrm{opal}}$ are the respective half saturation constants. The parameters $V_{\max }^{\mathrm{POC}}, V_{\max }^{\mathrm{opal}}, K_{\mathrm{s}}^{\mathrm{POC}}$, and $K_{\mathrm{s}}^{\mathrm{opal}}$ are prescribed as a function of sea surface temperature following Heinze et al. (2003).

$\mathrm{CaCO}_{3}$ export production depends on the local production ratio $P_{\mathrm{opal}} / P_{\mathrm{POC}}$. $\mathrm{CaCO}_{3}$ export starts to increase gradually when $P_{\text {opal }} / P_{\text {POC }}$ sinks below a threshold value $S_{\text {opal }}$, i.e. when the silicic acid concentration is becoming too small to support diatom growth exclusively:

$$
\begin{aligned}
& P_{\mathrm{CaCO}_{3}}=P_{\mathrm{POC}} \cdot R \cdot\left(1-\frac{P_{\mathrm{opal}} / P_{\mathrm{POC}}}{S_{\mathrm{opal}}}\right), \\
& \text { for } P_{\mathrm{opal}} / P_{\mathrm{POC}}<S_{\mathrm{opal}} ; \\
& P_{\mathrm{CaCO}_{3}}=0
\end{aligned}
$$

for $P_{\mathrm{opal}} / P_{\mathrm{POC}} \geq S_{\mathrm{opal}}$,

where $R$ is the maximum possible rain ratio $\mathrm{C}\left(\mathrm{CaCO}_{3}\right): \mathrm{C}(\mathrm{POC})$ and $S_{\text {opal }}$ is the threshold value of $P_{\text {opal }} / P_{\text {POC }}$ for gradual onset of $\mathrm{CaCO}_{3}$ production.

Particle fluxes and particle degradation are simulated through mass balance equations for sinking particulate matter $M_{\text {settle }}$, where $M_{\text {settle }}$ stands for any of the different particle species $\mathrm{POC}_{\text {settle }}, \mathrm{CaCO}_{3 \text { settle}}$, opal ${ }_{\text {settle}}$, and claysettle 
Table A1. Model parameter values as set for the control or standard run.

\begin{tabular}{|c|c|c|}
\hline Tunable model parameter & Parameter symbol & Control run value \\
\hline Specific gas exchange rate for $\mathrm{CO}_{2}$ & $k_{\mathrm{CO}_{2}}$ & $0.0603\left(\mathrm{~mol} \mathrm{~m}^{-2} \mathrm{yr}^{-1} \mathrm{ppm}^{-1}\right)$ \\
\hline $\mathrm{O}_{2}$ gas transfer velocity & $k_{\mathrm{O}_{2}}$ & $250\left(\mathrm{~m} \mathrm{yr}^{-1}\right)$ \\
\hline Threshold value $S_{\text {opal }}$ of particle & & 0.6 \\
\hline \multicolumn{3}{|l|}{ Export production ratio $\mathrm{C}(\mathrm{opal})$ : $\mathrm{C}(\mathrm{POC})$} \\
\hline for the onset of $\mathrm{CaCO}_{3}$ production (see Eq. 5) & & \\
\hline $\begin{array}{l}\text { Maximum possible production rain ratio } \mathrm{C}\left(\mathrm{CaCO}_{3}\right): \mathrm{C}(\mathrm{POC}) \\
\text { (see Eq. 12) }\end{array}$ & $R$ & 0.375 \\
\hline Global weathering input of $\mathrm{Si}$ & - & $4.5 \times 10^{12}(\mathrm{~mol} \mathrm{Si} \mathrm{yr}-1)$ \\
\hline Global weathering input of $\mathrm{CaCO}_{3}$ & - & $27 \cdot 10^{12}\left(\mathrm{molC} \mathrm{yr}^{-1}\right)$ \\
\hline Global weathering input of POC & - & $5 \times 10^{12}\left(\mathrm{~mol} \mathrm{Cyr}^{-1}\right)$ \\
\hline $\mathrm{Si}(\mathrm{OH})_{4}$ saturation concentration & $C_{\text {sat }}$ & $800\left(\mu \mathrm{mol} \mathrm{yr}^{-1}\right)$ \\
\hline Degradation rate constant of $\mathrm{CaCO}_{3}$ in water column & $r_{\mathrm{CaCO}_{3}}$ & $6.76\left(\mathrm{yr}^{-1}\right)$ \\
\hline Minimum value for $\mathrm{CaCO}_{3}$ undersaturation in water column & $\Omega_{\min }$ & 0.062 \\
\hline Degradation rate constant of opal in water column & $r_{\text {opal }}$ & $1.23\left(\mathrm{yr}^{-1}\right)$ \\
\hline Degradation rate constant of POC in water column & $r_{\mathrm{POC}}$ & $2.69\left(\mathrm{yr}^{-1}\right)$ \\
\hline Sinking velocity of particulate matter in water column & $w_{\mathrm{M}}$ & $3 \mathrm{~m}_{\text {day }}{ }^{-1}$ \\
\hline Degradation rate constant for dissolved & & $0.05\left(\mathrm{yr}^{-1}\right)$ \\
\hline \multicolumn{3}{|l|}{ Organic carbon in the water column } \\
\hline Degradation rate constant of $\mathrm{CaCO}_{3}$ in sediment & $r_{\mathrm{CaCO}_{3}}^{*}$ & $6.55 \times 10^{-4} / \mathrm{C}_{\mathrm{sat},}, \mathrm{CaCO}_{3}\left(\mathrm{yr}^{-1} \mathrm{~L} \mathrm{~mol}^{-1}\right)$ \\
\hline Degradation rate constant of opal in sediment & $r_{\text {opal }}^{*}$ & $9.82 \times 10^{-4} / \mathrm{C}_{\text {sat }, \text { opal }}\left(\mathrm{yr}^{-1} \mathrm{~L} \mathrm{~mol}^{-1}\right)$ \\
\hline Degradation rate constant of organic carbon in sediment & $r_{\text {orgC }}^{*}$ & $2.69 \times 10^{-4} / \mathrm{C}_{\mathrm{sat}, \mathrm{opal}}\left(\mathrm{yr}^{-1} \mathrm{~L} \mathrm{~mol}^{-1}\right)$ \\
\hline Diffusion constant for pore waters & $D_{\mathrm{w}}$ & $8 \times 10^{-6}\left(\mathrm{~cm}^{2} \mathrm{~s}^{-1}\right)$ \\
\hline Coefficient for explicit bioturbation & $D_{\mathrm{b}}$ & $40\left(\mathrm{~cm}^{2} / 1000\right.$ years $)$ \\
\hline
\end{tabular}

The general formulation for the mass balance $M_{\text {settle }}$ then becomes

$$
\begin{aligned}
& \frac{\mathrm{d} M_{\text {settle }}}{\mathrm{d} t}=\text { gain }- \text { loss } \\
& \frac{\mathrm{d} M_{\text {settle }}}{\mathrm{d} t}=P_{\mathrm{M}}-\frac{w_{\mathrm{M}}}{\Delta z_{0}} \cdot M_{\text {settle }}-r_{\mathrm{M}} \cdot M_{\text {settle }}
\end{aligned}
$$

(for surface layer)

$\frac{\mathrm{d} M_{\text {settle }}}{\mathrm{d} t}=w_{\mathrm{M}} \cdot \frac{\partial M_{\text {settle }}}{\partial z}-r_{\mathrm{M}} \cdot M_{\text {settle }}$

(for other layers),

where $\Delta z_{0}$ is the thickness of the euphotic zone [m], $w_{\mathrm{M}}$ is the particle settling velocity $\left[\mathrm{m} \mathrm{yr}^{-1}\right], r_{\mathrm{M}}$ is the reaction rate constant $\left[\mathrm{yr}^{-1}\right]$ for degradation of particulate matter, and $P_{\mathrm{M}}$ is the export production rate in the top layer, where again " $\mathrm{M}$ " denotes any of the particle species $\mathrm{POC}, \mathrm{CaCO}_{3}$, opal, and clay. $P_{\text {clay }}$ is the dust input from the atmosphere which is prescribed for the control run according to the modern dust deposition field from (Mahowald et al., 1999). Clay material is considered chemically inert. The system of Eq. (A9) is solved through an implicit numerical scheme. $\mathrm{CaCO}_{3}$ dissolution in the water column is performed depending on the prevailing carbonate saturation using the following rate constant:

$r_{\mathrm{CaCO}_{3}}=k_{\mathrm{CaCO}_{3}} \cdot(1-\Omega)$, where $k_{\mathrm{CaCO}_{3}}$ is a fixed standard rate constant, and $(1-\Omega)=$ $\left(\left[\mathrm{CO}_{3}^{2-}\right]_{\mathrm{sat}}-\left[\mathrm{CO}_{3}^{2-}\right]\right) /\left[\mathrm{CO}_{3}^{2-}\right]_{\mathrm{sat}}$ is the degree of undersaturation. Similar to Heinze et al. (2009) we apply a minimum value of 0.062 for the undersaturation, thus allowing for some $\mathrm{CaCO}_{3}$ dissolution in oversaturated waters (as a simplification, our model simulates only calcite and not the meta-stable form aragonite or high-Mg calcites). Opal dissolution is formulated to depend on the deviation from the saturation concentration for opal in seawater (following Ragueneau et al., 2000, where, in the formulation below, the effect of changes in free surface area of reactive opal is formally lumped into $k_{\text {opal }}$ here):

$r_{\text {opal }}=k_{\text {opal }} \cdot\left(\mathrm{Si}_{\text {saturation }}-\mathrm{Si}_{\text {actual }}\right) /\left(1 \mathrm{molL}^{-1}\right)$,

with $k_{\text {opal }}$ a standard upper limit opal degradation rate, $\mathrm{Si}_{\text {saturation }}$ the water column saturation value for silicic acid, and $\mathrm{Si}_{\text {actual }}$ the actual silicic acid value at a model grid point (the division by $1 \mathrm{~mol} \mathrm{~L}^{-1}$ is needed in order to match the units correctly).

The losses in particulate matter according to Eq. (A9) for settling particulate material are mirrored by respective source terms for the dissolved species within the water column (for TAlk, DIC, phosphate, oxygen, and silicic acid). The remainder of particles which are not subject to degradation within the water column are deposited onto the top sediment layer (see sedimentary source term $Q$ further below). 


\section{A3 Sediment pore water chemistry and diffusion}

Early diagenetic processes are simulated as described in Heinze et al. (2009), following the efficient numerical formulations of Maier-Reimer et al. (2005) for the implicit simultaneous treatment of pore water transport and pore water reactions as well as the vertical sediment advection. The porosity depth profile is fixed using numerical values of Ullman and Aller (1982). The basic sediment model concept is expressed through the equilibrium expressed by the following equation:

sediment accumulation $=$ deposition - redissolution.

The mass balance equations for a solid sediment component (expressed in moles per unit volume of sediment $S_{*}$ ) and the related concentration of the corresponding dissolved substance $C$ within the pore water are

$$
\begin{aligned}
\frac{\mathrm{d} S_{*}}{\mathrm{~d} t} & =D_{\mathrm{B}} \frac{\partial^{2} S_{*}}{\partial z^{2}}-\frac{\partial}{\partial z}\left(w \cdot S_{*}\right)-G, \\
\frac{\mathrm{d} C}{\mathrm{~d} t} & =\frac{\partial}{\partial z}\left(D_{\mathrm{W}} \frac{\partial C}{\partial z}\right)+G,
\end{aligned}
$$

where $D_{\mathrm{B}}$ is the diffusion coefficient for bioturbation, $w$ the vertical advection velocity of solid compound, and $G$ the reaction rate (with $S_{*}, C$, and $G$ reported here in relation to full sediment volume of a given sediment layer for sake of simplicity; within the model, the varying volumes for dissolved and solid substances following the porosity profile are taken into account). The prognostic equations for solid sediment concentrations $S_{*}$ (organic carbon, $\mathrm{CaCO}_{3}$, opal, and clay) and for dissolved components $C$ (TAlk, DIC, phosphate, oxygen, and silicic acid) are coupled through the respective reaction rates. The diffusive transport of pore water tracer concentrations is simulated via the respective deviations from saturation in parallel with the reduction in this deviation due to chemical pore water reactions:

$\frac{\mathrm{d} U}{\mathrm{~d} t}=\frac{\partial}{\partial z}\left(D_{\mathrm{W}} \frac{\partial U}{\partial z}\right)-G$,

where $U$ is the deviation of the saturation concentration, $C_{\text {sat }}$, from the actual concentration $C$ ) $\left[\mathrm{mol} \mathrm{L}^{-1}\right], G$ is the reaction rate (sink for $U$ from dissolution of solid material) $\left[\mathrm{mol} \mathrm{L}^{-1} \mathrm{yr}^{-1}\right]$, and $D_{\mathrm{W}}$ is the diffusion coefficient. As diffusion coefficient, $D_{\mathrm{W}}$, we employ a general value of $8 \times 10^{-6} \mathrm{~cm}^{2} \mathrm{~s}^{-1}$ for all pore water tracers (this value is in the range of the values given for various pore water species in the work of Li and Gregory, 1974). The solid sediment components change due to pore water reactions and particle deposition corresponding to Eq. (A14):

$\frac{\mathrm{d} S_{*}}{\mathrm{~d} t}=-G+Q$,

where $S_{*}$ is the solid sediment component expressed in the same units as $U\left[\mathrm{~mol} \mathrm{~L}^{-1}\right], G$ is the reaction rate (sink due to dissolution) $\left[\mathrm{mol} \mathrm{L}^{-1} \mathrm{yr}^{-1}\right]$, and $Q$ is the deposition flux from particle rain $\left[\mathrm{mol} \mathrm{L}^{-1} \mathrm{yr}^{-1}\right.$ ] (the last of which occurs only in the top sediment layer). The amount $G$ of solid matter which can be dissolved per unit of time is a function of parameter $r_{c}^{*}$, the deviation from saturation concentration $U$, and the amount of solid material available $S_{*}$ :

$G=r_{c}^{*} \cdot U \cdot S_{*}$,

where for $r_{c}^{*}$ we have

$r_{c}^{*}=\frac{r_{c}}{C_{\mathrm{sat}}}$

with $r_{c}$ being the reaction rate constant $\left[\mathrm{yr}^{-1}\right]$ and $C_{\text {sat }}$ the saturation concentration in solution $\left[\mathrm{mol} \mathrm{L}^{-1}\right]$. For opal dissolution a solubility $C_{\text {sat }}$ of $800 \mu \mathrm{mol} \mathrm{L}^{-1}$ is used (see Dixit et al., 2001), and for organic carbon a constant formal value of $100 \mu \mathrm{mol} \mathrm{L}^{-1}$ is used (details of anaerobic respiration and respective effects such as denitrification and sulphate reduction are not explicitly taken into account). For the sedimentary $\mathrm{CaCO}_{3}$, the $\mathrm{CO}_{3}^{2-}$ saturation concentration is now also computed through the revised inorganic carbon system quantification following Dickson et al. (2007) (see Eq. A10). The discretised versions of the coupled Eqs. (A14 and A15) are solved implicitly through a numerical back-substitution formulation. Transport of dissolved tracers through pore water diffusion is not carried out as a boundary condition problem. Rather, we formally include the lowermost wet grid box in the water column directly over the model seafloor in the pore water diffusion scheme. Thus, the free water column and the sediment pore waters directly exchange matter with each other.

\section{A4 Bioturbation}

Bioturbation is simulated as in Heinze et al. (2009) through vertical "diffusion" of the solid substances. This step is carried out after the vertical advection step described further below. The solid matter compounds are slowly mixed in proportion to the prevailing weight fractions in the layers overlying each other:

$\frac{\mathrm{d} S_{*}}{\mathrm{~d} t}=\frac{\partial}{\partial z}\left(D_{\mathrm{B}} \frac{\partial S_{*}}{\partial z}\right)$,

with $D_{\mathrm{B}}$ being the bioturbation coefficient. Non-local mixing (e.g. Boudreau and Imboden, 1987) is neglected here.

\section{A5 Advection of solid sediment weight fractions and sediment accumulation}

Vertical advection of sediment is performed as in Heinze et al. (2009), where the direction of sediment accumulation depends on the amount of the matter deposited onto the top sediment layer, and the redissolution rate of matter within the sediment mixed layer. The four different weight fractions 
clay, $\mathrm{CaCO}_{3}$, opal, $\mathrm{POC}$, and POP are shifted downward or upward according to the gain from the deposition flux and the gaps which are created from dissolution. In the case of very strong corrosion in the bioturbated zone, only clay is transported upward from below the sediment mixed layer. For an illustration of the mode of sediment advection for the different cases (a) burial $>$ rain - redissolution (accumulation of sediment) and (b) burial $<$ rain - (erosion of sediment), see Fig. 2 in Heinze et al. (2009). The vertical sediment advection velocity $w$ and also its sign (see Eq. A12) depend on the sediment deposition from the water column and the strength of the pore water chemical reactions. 
Acknowledgements. We would like to thank David Archer and an anonymous reviewer for their expert comments which improved the manuscript. Thanks are due to many colleagues and friends. Ernst Maier-Reimer (Max Planck Institute for Meteorology) provided the basic HAMOCC model and crucial advice on efficient numerical modelling. Marion Gehlen and James Orr provided help for revising the model inorganic chemistry treatment for using the appropriate $\mathrm{pH}$ scale. Thanks are due to Natalie Mahowald for providing the dust deposition fields. Elizabeth Farmer's language revision in busy times is highly appreciated. Arne Winguth is supported by grant NSF-OCE 1536630 and NSF-EAR 1636629. This work was partially supported through the University of Bergen (sabbatical funds for C. Heinze) through the "European Project on Ocean Acidification" (EPOCA, which received funding from the European Community's Seventh Framework Programme (FP7/2007-2013) under grant agreement no. 211384). The Research Council of Norway supported this study through the nationally coordinated project "Earth system modelling of climate variations in the Anthropocene" (EVA; grant no. 229771) as well as the project "Overturning circulation and its implications for global carbon cycle in coupled models" (ORGANIC; grant no. 239965). This is a contribution to the Bjerknes Centre for Climate Research (Bergen, Norway). A part of the computations were carried out under project NN2980K at the Norwegian Metacenter for Computational Science (NOTUR) and its dedicated storage and archiving project NorStore (NS2980k).

Edited by: A. Haywood

Reviewed by: D. Archer and one anonymous referee

\section{References}

Abernathey, R., Cerovecki, I., Holland, P., Newsom, E., Mazloff, M., and Talley, L.: Water-mass transformation by sea ice in the upper branch of the Southern Ocean overturning, Nat. Geosci., doi:10.1038/NGEO2749, in press, 2016.

Adkins, J., McIntyre, K., and Schrag, D.: The salinity, temperature, and delta O-18 of the glacial deep ocean, Science, 298, 17691773, doi:10.1126/science.1076252, 2002.

Anklin, M., Barnola, J., Beer, J., Blunier, T., Chappellaz, J., Clausen, H., Dahljensen, D., Dansgaard, W., Deangelis, M., Delmas, R., Duval, P., Fratta, M., Fuchs, A., Fuhrer, K., Gundestrup, N., Hammer, C., Iversen, P., Johnsen, S., Jouzel, J., Kipfstuhl, J., Legrand, M., Lorius, C., Maggi, V., Miller, H., Moore, J., Oeschger, H., Orombelli, G., Peel, D., Raisbeck, G., Raynaud, D., Schotthvidberg, C., Schwander, J., Shoji, H., Souchez, R., Stauffer, B., Steffensen, J., Stievenard, M., Sveinbjornsdottir, A., Thorsteinsson, T., and Wolff, E.: Climate instability during the last interglacial period recorded in the grip ice core, Nature, 364, 203-207, 1993.

Archer, D. and Maier-Reimer, E.: Effect of deep-sea sedimentary calcite preservation on atmospheric $\mathrm{CO}_{2}$ concentration, Nature, 367, 260-263, doi:10.1038/367260a0, 1994.

Archer, D., Lyle, M., Rodgers, K., and Froelich, P.: What controls opal preservation in tropical deep-sea sediments, Paleoceanography, 8, 7-21, doi:10.1029/92PA02803, 1993.

Archer, D., Winguth, A., Lea, D., and Mahowald, N.: What caused the glacial/interglacial atmospheric $p \mathrm{CO}_{2}$ cycles?, Rev. Geophys., 38, 159-189, doi:10.1029/1999RG000066, 2000.
Armstrong, R., Lee, C., Hedges, J., Honjo, S., and Wakeham, S.: A new, mechanistic model for organic carbon fluxes in the ocean based on the quantitative association of POC with ballast minerals, Deep-Sea Res. Pt. II, 49, 219-236, 2002.

Bainbridge, A. E.: GEOSECS Atlantic Expedition, Volume 1, Hydrographic Data 1972-1973, National Science Foundation. Superintendent of Documents, US Government Prining Office, Washington D.C., 20402, 121 pp., 1981.

Barker, S. and Elderfield, H.: Foraminiferal calcification response to glacial-interglacial changes in atmospheric $\mathrm{CO}_{2}$, Science, 297, 833-836, doi:10.1126/science.1072815, 2002.

Barker, S., Chen, J., Gong, X., Jonkers, L., Knorr, G., and Thornalley, D.: Icebergs not the trigger for North Atlantic cold events, Nature, 520, 333-338, doi:10.1038/nature14330, 2015.

Barnola, J., Raynaud, D., Korotkevich, Y., and Lorius, C.: Vostok ice core provides 160,000-year record of atmospheric $\mathrm{CO}_{2}, \mathrm{Na}$ ture, 329, 408-414, doi:10.1038/329408a0, 1987.

Becquey, S. and Gersonde, R.: Past hydrographic and climatic changes in the Subantarctic Zone of the South Atlantic - The Pleistocene record from ODP Site 1090, Palaeogeogr. Palaeocl., 182, 221-239, doi:10.1016/S0031-0182(01)00497-7, 2002.

Becquey, S. and Gersonde, R.: A 0.55-Ma paleotemperature record from the Subantarctic zone: Implications for Antarctic Circumpolar Current development, Paleoceanography, 18, 1014, doi:10.1029/2000PA000576, 2003.

Bellerby, R. G. J., Schulz, K. G., Riebesell, U., Neill, C., Nondal, G., Heegaard, E., Johannessen, T., and Brown, K. R.: Marine ecosystem community carbon and nutrient uptake stoichiometry under varying ocean acidification during the PeECE III experiment, Biogeosciences, 5, 1517-1527, doi:10.5194/bg-5-15172008, 2008.

Berger, W. and Keir, R.: Glacial-Holocene Changes in Atmospheric $\mathrm{CO}_{2}$ and the Deep-Sea Record, American Geophysical Union, Washington, D.C., edited by: Hansen, J. E. and Takahashi, T., Geophysical Monograph, 29, 337-351, doi:10.1029/GM029p0337, 1984.

Berger, W. and Wefer, G.: Productivity of the glacial ocean - discussion of the iron hypothesis, Limnol. Oceanogr., 36, 1899-1918, doi:10.4319/lo.1991.36.8.1899, 1991.

Bickert, T.: Rekonstruktion der spätquartären Bodenwasserzirkulation im östlichen Südatlantik über stabile Isotope benthischer Foraminiferen, Berichte, Fachbereich Geowissenschaften, Universität Bremen, Bremen, 27, 205 pp., 1992.

Bickert, T. and Mackensen, A.: Last Glacial to Holocene changes in South Atlantic deep water circulation, edited by: Wefer, G., Mulitza, S., and Ratmeyer, S., Springer-Verlag, Berlin, Heidelberg, New York, Tokyo, 671-695, 1996.

Bickert, T. and Wefer, G.: Late Quaternary deep water circulation in the South Atlantic: Reconstruction from carbonate dissolution and benthic stable isotopes, edited by: Wefer, G., Berger, W. H., Siedler, G., and Webb, D., Springer-Verlag, Berlin, 599-620, 1996.

Bidle, K. and Azam, F.: Accelerated dissolution of diatom silica by marine bacterial assemblages, Nature, 397, 508-512, doi:10.1038/17351, 1999.

Bolin, B. and Eriksson, E.: Changes in the carbon dioxide content of the atmosphere and sea due to fossil fuel combustion, edited by: Bolin, B., Rockefeller Inst., New York, Rossby Memorial Volume, 130-142, 1959. 
Bond, G., Broecker, W., Johnsen, S., McManus, J., Labeyrie, L., Jouzel, J., and Bonani, G.: Correlations between climate records from North Atlantic sediments and Greenland ice, Nature, 365, 143-147, doi:10.1038/365143a0, 1993.

Boudreau, B.: Diagenetic models and their implementation: modelling transport and reactions in aquatic sediments, Springer, Berlin and Heidelberg, 414 pp., 1997.

Boudreau, B. and Imboden, D.: Mathematics of tracer mixing in sediments. 3. The theory of nonlocal mixing within sediments, Am. J. Sci. 287, 693-719, doi:10.2475/ajs.287.7.693, 1987.

Boyle, E.: Vertical oceanic nutrient fractionation and glacial interglacial $\mathrm{CO}_{2}$ cycles, Nature, 331, 55-56, doi:10.1038/331055a0, 1988a.

Boyle, E.: Glacial interglacial deep ocean circulation contrast, Chem. Geol., 70, 108-108, doi:10.1016/0009-2541(88)90504-9, 1988b.

Broecker, W.: Ocean chemistry during glacial time, Geochim. Cosmochim. Ac., 46, 1689-1705, doi:10.1016/00167037(82)90110-7, 1982.

Broecker, W.: Oxygen isotope constraints on surface ocean temperatures, Quaternary Res., 26, 121-134, doi:10.1016/00335894(86)90087-6, 1986.

Broecker, W. and Peng, T.: Carbon cycle - 1985 Glacial to interglacial changes in the operation of the global carbon cycle, Radiocarbon, 28, 309-327, 1986.

Broecker, W., Peacock, S., Walker, S., Weiss, R., Fahrbach, E., Schroeder, M., Mikolajewicz, U., Heinze, C., Key, R., Peng, T., and Rubin, S.: How much deep water is formed in the Southern Ocean?, J. Geophys. Res.-Oceans, 103, 15 833-15 843, doi:10.1029/98JC00248, 1998.

Brovkin, V., Ganopolski, A., Archer, D., and Rahmstorf, S.: Lowering of glacial atmospheric $\mathrm{CO}_{2}$ in response to changes in oceanic circulation and marine biogeochemistry, Paleoceanography, 22, PA4202, doi:10.1029/2006PA001380, 2007.

Caldeira, K. and Wickett, M. E.: Oceanography: anthropogenic carbon and ocean pH, Nature, 425, 365-365, doi:10.1038/425365a, 2003.

Carter, L. and Manighetti, B.: Glacial/interglacial control of terrigenous and biogenic fluxes in the deep ocean off a high input, collisional margin: A 139 kyr-record from New Zealand, Mar. Geol., 226, 307-322, doi:10.1016/j.margeo.2005.11.004, 2006.

Carter, L., Manighetti, B., Ganssen, G., and Northcote, L.: Southwest Pacific modulation of abrupt climate change during the Antarctic Cold Reversal - Younger Dryas, Palaeogeogr. Palaeocl., 260, 284-298, doi:10.1016/j.palaeo.2007.08.013, 2008.

Charles, C., Froelich, P., Zibello, M., Mortlock, R., and Morley, J.: Biogenic opal in southern ocean sediments over the last 450,000 years: implications for surface water chemistry and circulation, Paleoceanography, 6, 697-728, doi:10.1029/91PA02477, 1991.

Chuey, J., Rea, D., and Pisias, N.: Late Pleistocene Paleoclimatology of the central equatorial Pacific - a quantitative record of eolian and carbonate deposition, Quaternary Res., 28, 323-339, doi:10.1016/0033-5894(87)90001-9, 1987.

Ciais, P., Tagliabue, A., Cuntz, M., Bopp, L., Scholze, M., Hoffmann, G., Lourantou, A., Harrison, S., Prentice, I., Kelley, D., Koven, C., and Piao, S.: Large inert carbon pool in the terres- trial biosphere during the Last Glacial Maximum, Nat. Geosci., 5, 74-79, doi:10.1038/NGEO1324, 2012.

CLIMAP Project Members: The surface of the ice-age Earth, Science, 191, 1131-1137, 1976.

CLIMAP Project Members: Seasonal Reconstruction of the Earth's surface at the Last Glacial Maximum, Geol. Soc. Am. Map Chart Ser., 36, 1981.

Conway, T., Wolff, E., Roethlisberger, R., Mulvaney, R., and Elderfield, H.: Constraints on soluble aerosol iron flux to the Southern Ocean at the Last Glacial Maximum, Nature Communications, 6, 1-9, doi:10.1038/ncomms8850, 2015.

Crowley, T.: Ice-age terrestrial carbon changes revisited, Global Biogeochem. Cy., 9, 377-389, doi:10.1029/95GB01107, 1995.

Curry, W. and Oppo, D.: Synchronous, high-frequency oscillations in tropical sea surface temperatures and North Atlantic Deep Water production during the last glacial cycle, Paleoceanography, 12, 1-14, doi:10.1029/96PA02413, 1997.

Curry, W., Duplessy, J., Labeyrie, L., and Shackleton, N.: Changes in the distribution of $\delta^{13} \mathrm{C}$ of deep water $\Sigma \mathrm{CO}_{2}$ between the last glaciation and the Holocene, Paleoceanography, 3, 317-341, doi:10.1029/PA003i003p00317, 1988.

Cutler, K., Edwards, R., Taylor, F., Cheng, H., Adkins, J., Gallup, C., Cutler, P., Burr, G., and Bloom, A.: Rapid sea-level fall and deep-ocean temperature change since the last interglacial period, Earth Planet. Sc. Lett., 206, 253-271, doi:10.1016/S0012821X(02)01107-X, 2003.

Dansgaard, W., Johnsen, S., Clausen, H., Dahljensen, D., Gundestrup, N., Hammer, C., Hvidberg, C., Steffensen, J., Sveinbjornsdottir, A., Jouzel, J., and Bond, G.: Evidence for general instability of past climate from a 250-kyr ice-core record, Nature, 364, 218-220, doi:10.1038/364218a0, 1993.

Dickson, A., Sabine, C., and Christian, J., eds.: Guide to best practices for ocean $\mathrm{CO}_{2}$ measurements, North Pacific Marine Science Organization, Sidney BC, Canada, PICES Special Publication 3, IOCCP Report No. 8, 191 pp., 2007.

Dixit, S., Van Cappellen, P., and van Bennekom, A.: Processes controlling solubility of biogenic silica and pore water build-up of silicic acid in marine sediments, Mar. Chem., 73, 333-352, doi:10.1016/S0304-4203(00)00118-3, 2001.

Downes, S., Farneti, R., Uotila, P., Griffies, S., Marsland, S., Bailey, D., Behrens, E., Bentsen, M., Bi, D., Biastoch, A., Boening, C., Bozec, A., Canuto, V., Danabasoglu, E. C. G., Danilov, S., Diansky, N., Drange, H., Fogli, P., Gusev, A., Howard, A., Ilicak, M., Jung, T., Kelley, M., Large, W., Leboissetier, A., Long, M., Lu, J., Masina, S., Mishra, A., Navarra, A., Nurser, A., Patara, L., Samuels, B., Sidorenko, D., Spence, P., Tsujino, H., Wang, Q., and Yeager, S.: An assessment of Southern Ocean water masses and sea ice during 1988-2007 in a suite of interannual CORE-II simulations, Ocean Model., 94, 67-94, doi:10.1016/j.ocemod.2015.07.022, 2015.

Dürkoop, A., Hale, W., Mulitza, S., Pätzold, J., and Wefer, G.: Late Quaternary variations of sea surface salinity and temperature in the western tropical Atlantic: Evidence from delta O-18 of Globigerinoides sacculifer, Paleoceanography, 12, 764-772, doi:10.1029/97PA02270, 1997.

Dwyer, G., Cronin, T., Baker, P., Raymo, M., Buzas, J., and Correge, T.: North-Atlantic deep-water temperature-change during the late Pliocene and late quaternary climatic cycles, Science, 270, 13471351, doi:10.1126/science.270.5240.1347, 1995. 
Edmond, J. and Gieskes, J.: On the calculation of the degree of saturation of sea water with respect to calcium carbonate under in situ conditions, Geochim. Cosmochim. Ac., 34, 1261-1291, doi:10.1016/0016-7037(70)90041-4, 1970.

Farneti, R., Downes, S., Griffies, S., Marsland, S., Behrens, E., Bentsen, M., Bi, D., Biastoch, A., Boening, C., Bozec, A., Canuto, V., Chassignet, E., Danabasoglu, G., Danilov, S., Diansky, N., Drange, H., Fogli, P., Gusev, A., Hallberg, R., Howard, A., Ilicak, M., Jung, T., Kelley, M., Large, W., Leboissetier, A., Long, M., Lu, J., Masina, S., Mishra, A., Navarra, A., Nurser, A., Patara, L., Samuels, B., Sidorenko, D., Tsujino, H., Uotil, P., Wang, Q., and Yeager, S.: An assessment of Antarctic Circumpolar Current and Southern Ocean meridional overturning circulation during 1958-2007 in a suite of interannual CORE-II simulations, Ocean Model., 93, 84-120, doi:10.1016/j.ocemod.2015.07.009, 2015.

Freudenthal, T.: Reconstruction of productivity gradients in the Canary Island Region off Morocco by means of sinking particles and sediments, Berichte, Fachbereich Geowissenschaften, Universität Bremen, Bremen, 165, 147 pp., 1998.

Freudenthal, T., Meggers, H., Henderiks, J., Kuhlmann, H., Moreno, A., and Wefer, G.: Upwelling intensity and filament activity off Morocco during the last 250,000 years, Deep-Sea Res. Pt. 2, 49, 3655-3674, doi:10.1016/S0967-0645(02)001017, 2002.

Gattuso, J. and Hansson, L. (Eds.): Ocean acidification, Oxford University Press, New York, 326 pp., 2011.

Gordon, A.: Deep Antarctic convection west of Maud Rise, J. Phys. Oceanogr., 8, 600-612, doi:10.1175/15200485(1978)008<0600:DACWOM>2.0.CO;2, 1978.

Gottschalk, J., Skinner, L., Lippold, J., Vogel, H., Frank, N., Jaccard, S., and Waelbroeck, C.: Biological and physical controls in the Southern Ocean on past millennial-scale atmospheric $\mathrm{CO}_{2}$ changes, Nature Communications, 7, 1-11, doi:10.1038/ncomms11539, 2016.

Greene, A. M., Seager, R., and Broecker, W. S.: Tropical snowline depression at the Last Glacial Maximum: Comparison with proxy records using a single-cell tropical climate model, J. Geophys. Res.-Atmos., 107, 4061, doi:10.1029/2001JD000670, 2002.

Griffiths, J. D., Barker, S., Hendry, K. R., Thornalley, D. J. R., van de Flierdt, T., Hall, I. R., and Anderson, R. F.: Evidence of silicic acid leakage to the tropical Atlantic via Antarctic Intermediate Water during Marine Isotope Stage 4, Paleoceanography, 28, 307-318, doi:10.1002/palo.20030, 2013.

Haugan, P. and Drange, H.: Effects of $\mathrm{CO}_{2}$ on the ocean environment, Energ. Convers. Manage., 37, 1019-1022, doi:10.1016/0196-8904(95)00292-8, 1996.

Heinze, C.: Towards the time dependent modeling of sediment core data on a global basis, Geophys. Res. Lett., 28, 4211-4214, doi:10.1029/2001GL013479, 2001.

Heinze, C. and Hasselmann, K.: Inverse multiparameter modeling of paleoclimate carbon cycle indices, Quaternary Res., 40, 281296, doi:10.1006/qres.1993.1082, 1993.

Heinze, C. and Maier-Reimer, E.: The Hamburg Oceanic Carbon Cycle Circulation Model Version "HAMOCC2s" for long time integrations, Tech. rep., Max Planck Institute for Meteorology, Hamburg, Germany, Series: Technical Reports, no. 20, ISSN 0940-9327, 1999.
Heinze, C., Maier-Reimer, E., and Wynn, K.: Glacial $p \mathrm{CO}_{2}$ reduction by the world ocean: Experiments with the $\mathrm{Hm}$ burg carbon cycle model, Paleoceanography, 6, 395-430, doi:10.1029/91PA00489, 1991.

Heinze, C., Maier-Reimer, E., Winguth, A., and Archer, D.: A global oceanic sediment model for long-term climate studies, Global Biogeochem. Cy., 13, 221-250, doi:10.1029/98GB02812, 1999.

Heinze, C., Hupe, A., Emaier-Reimer, Dittert, N., and Ragueneau, O.: Sensitivity of the marine biospheric Si cycle for biogeochemical parameter variations, Global Biogeochem. Cy., 17, 1086, doi:10.1029/2002GB001943, 2003.

Heinze, C., Gehlen, M., and Land, C.: On the potential of ${ }^{230} \mathrm{Th},{ }^{231} \mathrm{~Pa}$, and ${ }^{10} \mathrm{Be}$ for marine rain ratio determinations: A modeling study, Global Biogeochem. Cy., 20, GB2018, doi:10.1029/2005GB002595, 2006.

Heinze, C., Kriest, I., and Maier-Reimer, E.: Age offsets among different biogenic and lithogenic components of sediment cores revealed by numerical modeling, Paleoceanography, 24, PA4214, doi:10.1029/2008PA001662, 2009.

Hodell, D.: Late Pleistocene paleoceanography of the South Atlantic sector of the Southern Ocean: Ocean Drilling Program Hole 704A, Paleoceanography, 8, 47-67, doi:10.1029/92PA02774, 1993.

Hodell, D., Charles, C., Curtis, J., Mortyn, P., Ninnemann, U., and Venz, K.: Data Report: Oxygen isotope stratigraphy of ODP Leg 117 sites 1088, 1089, 1090, 1093, and 1094, edited by: Gersonde, R., Hodell, D. A., and Blum, P., ODP, College Station, TX, 1-26, doi:10.2973/odp.proc.sr.177.120.2003, 2003a.

Hodell, D., Venz, K., Charles, C., and Ninnemann, U.: Pleistocene vertical carbon isotope and carbonate gradients in the South Atlantic sector of the Southern Ocean, Geochem. Geophy. Geosy., 4, 1004, doi:10.1029/2002GC000367, 2003b.

Hoogakker, B. A. A., Smith, R. S., Singarayer, J. S., Marchant, R., Prentice, I. C., Allen, J. R. M., Anderson, R. S., Bhagwat, S. A., Behling, H., Borisova, O., Bush, M., Correa-Metrio, A., de Vernal, A., Finch, J. M., Fréchette, B., Lozano-Garcia, S., Gosling, W. D., Granoszewski, W., Grimm, E. C., Grüger, E., Hanselman, J., Harrison, S. P., Hill, T. R., Huntley, B., Jiménez-Moreno, G., Kershaw, P., Ledru, M.-P., Magri, D., McKenzie, M., Müller, U., Nakagawa, T., Novenko, E., Penny, D., Sadori, L., Scott, L., Stevenson, J., Valdes, P. J., Vandergoes, M., Velichko, A., Whitlock, C., and Tzedakis, C.: Terrestrial biosphere changes over the last 120?kyr, Clim. Past, 12, 51-73, doi:10.5194/cp-12-51-2016, 2016.

Hoogakker, B., Elderfield, H., Schmiedl, G., McCave, I., and Rickaby, R.: Glacial-interglacial changes in bottom-water oxygen content on the Portuguese margin, Nat. Geosci., 8, 40-43, doi:10.1038/NGEO2317, 2015.

Howard, W. and Prell, W.: Late Quaternary surface circulation of the southern Indian Ocean and its relationship to orbital variations, Paleoceanography, 7, 79-117, doi:10.1029/91PA02994, 1992.

Hyun, S., Ahagon, N., and Yoon, H.: Milankovitch cycles and paleoceanographic evolution within sediments from ODP Sites 980 and 983 of the North Atlantic Ocean, Geosci. J., 9, 235-242, doi:10.1007/BF02910583, 2005.

Iglesias-Rodriguez, M. D., Halloran, P. R., Rickaby, R. E. M., Hall, I. R., Colmenero-Hidalgo, E., Gittins, J. R., Green, 
D. R. H., Tyrrell, T., Gibbs, S. J., von Dassow, P., Rehm, E., Armbrust, E. V., and Boessenkool, K. P.: Phytoplankton calcification in a high- $\mathrm{CO}_{2}$ world., Science, 320, 336-40, doi:10.1126/science.1154122, 2008.

Imbrie, J., McIntyre, A., and Mix, A.: Oceanic response to orbital forcing in the late Quaternary: observational and experimental strategies, edited by: Berger, A., Schneider, S. H., and J.-C. Duplessy, Kluwer Academic, Boston, 121-164, 1989.

Ingle, S.: Solubility of calcite in the ocean, Mar. Chem., 3, 301-319, doi:10.1016/0304-4203(75)90010-9, 1975.

Joos, F., Roth, R., Fuglestvedt, J. S., Peters, G. P., Enting, I. G., von Bloh, W., Brovkin, V., Burke, E. J., Eby, M., Edwards, N. R., Friedrich, T., Frölicher, T. L., Halloran, P. R., Holden, P. B., Jones, C., Kleinen, T., Mackenzie, F. T., Matsumoto, K., Meinshausen, M., Plattner, G.-K., Reisinger, A., Segschneider, J., Shaffer, G., Steinacher, M., Strassmann, K., Tanaka, K., Timmermann, A., and Weaver, A. J.: Carbon dioxide and climate impulse response functions for the computation of greenhouse gas metrics: a multi-model analysis, Atmos. Chem. Phys., 13, 2793 2825, doi:10.5194/acp-13-2793-2013, 2013.

Jouzel, J.: EPICA Dome C Ice Cores Deuterium Data, IGBP PAGES, World Data Center for Paleoclimatology, Data Contribution Series no. 2004-038. NOAA/NGDC Paleoclimatology Program, Boulder CO, USA, doi:10.3334/CDIAC/cli.007, 2004.

Jouzel, J., Lorius, C., Petit, J., Genthon, C., Barkov, N., Kotlyakov, V., and Petrov, V.: Vostok ice core - a continuous isotope temperature record over the last climatic cycle (160,000 years), Nature, 329, 403-408, doi:10.1038/329403a0, 1987.

Jung, S. and Sarnthein, M.: Stable isotope data of sediment cores GIK23415-9, data set, PANGAEA, doi:10.1594/PANGAEA.112912, 2003a.

Jung, S. and Sarnthein, M.: Stable isotope data of sediment cores GIK23414-9, data set, PANGAEA, doi:10.1594/PANGAEA.112911, 2003 b.

Jung, S. and Sarnthein, M.: Stable isotope analysis of foraminifera from sediment cores GIK17049-6, data set, PANGAEA, doi:10.1594/PANGAEA.112908, 2004a.

Jung, S. and Sarnthein, M.: Stable isotope data of sediment cores GIK23418-8, data set, PANGAEA, doi:10.1594/PANGAEA.136425, 2004b.

Kawahata, H., Suzuki, A., and Ahagon, N.: Biogenic sediments in the West Caroline Basin, the western equatorial Pacific during the last 330,000 years, Mar. Geol., 149, 155-176, doi:10.1016/S0025-3227(98)00039-5, 1998.

Kawahata, H., Okamoto, T., Matsumoto, E., and Ujiie, H.: Fluctuations of eolian flux and ocean productivity in the mid-latitude North Pacific during the last 200 kyr, Quaternary Sci. Rev., 19, 1279-1291, doi:10.1016/S0277-3791(99)00096-7, 2000.

Kawamura, H., Holbourn, A., and Kuhnt, W.: Climate variability and land-ocean interactions in the Indo Pacific Warm Pool: A 460-ka palynological and organic geochemical record from the Timor Sea, Marine Micropaleontol., 59, 1-14, doi:10.1016/j.marmicro.2005.09.001, 2006.

Keigwin, L.: Radiocarbon and stable isotope constraints on Last Glacial Maximum and Younger Dryas ventilation in the western North Atlantic, Paleoceanography, 19, PA4012, doi:10.1029/2004PA001029, 2004.

Kirst, G.: Rekonstruktion von Oberflächenwassertemperaturen im östlichen Südatlantik anhand von Alkenonen, Berichte, Fach- bereich Geowissenschaften, Universität Bremen, Bremen, 118, 130 pp., 1998.

Kirst, G., Schneider, R., Müller, P., Von Storch, I., and Wefer, G.: Late Quaternary temperature variability in the Benguela Current System derived from alkenones, Quaternary Res., 52, 92-103, doi:10.1006/qres.1999.2040, 1999.

Klaas, C. and Archer, D.: Association of sinking organic matter with various types of mineral ballast in the deep sea: Implications for the rain ratio, Global Biogeochem. Cy., 16, 1116, doi:10.1029/2001GB001765, 2002.

Kuhn, G.: Calcium carbonate content of sediment core PS2489-2, Alfred Wegener Institute for Polar and Marine Research, Bremerhaven, data set, PANGAEA, doi:10.1594/PANGAEA.56102, 1999.

Lambert, F., Tagliabue, A., Shaffer, G., Lamy, F., Winckler, G., Farias, L., Gallardo, L., and Pol-Holz, R. D.: Dust fluxes and iron fertilization in Holocene and Last Glacial Maximum climates, Geophys. Res. Lett., 42, 6014-6023, doi:10.1002/2015GL064250, 2015.

LaMontagne, R., Murray, R., Wei, K., Leinen, M., and Wang, C.: Decoupling of carbonate preservation, carbonate concentration, and biogenic accumulation: A 400-kyr record from the central equatorial Pacific Ocean, Paleoceanography, 11, 553-562, doi:10.1029/96PA02249, 1996.

Lanczos, C.: Linear differential operators, D. Van Nostrand Company Ltd., London, New York, 564 pp., 1961.

Laws, E., Falkowski, P., Smith, W., Ducklow, H., and McCarthy, J.: Temperature effects on export production in the open ocean, Global Biogeochem. Cy., 14, 1231-1246, doi:10.1029/1999GB001229, 2000.

Lean, C. and McCave, I.: Glacial to interglacial mineral magnetic and palaeoceanographic changes at Chatham Rise, SW Pacific Ocean, Earth Planet. Sc. Lett., 163, 247-260, doi:10.1016/S0012-821X(98)00191-5, 1998.

Le Quéré, C., Peters, G. P., Andres, R. J., Andrew, R. M., Boden, T. A., Ciais, P., Friedlingstein, P., Houghton, R. A., Marland, G., Moriarty, R., Sitch, S., Tans, P., Arneth, A., Arvanitis, A., Bakker, D. C. E., Bopp, L., Canadell, J. G., Chini, L. P., Doney, S. C., Harper, A., Harris, I., House, J. I., Jain, A. K., Jones, S. D., Kato, E., Keeling, R. F., Klein Goldewijk, K., Körtzinger, A., Koven, C., Lefèvre, N., Maignan, F., Omar, A., Ono, T., Park, G.-H., Pfeil, B., Poulter, B., Raupach, M. R., Regnier, P., Rödenbeck, C., Saito, S., Schwinger, J., Segschneider, J., Stocker, B. D., Takahashi, T., Tilbrook, B., van Heuven, S., Viovy, N., Wanninkhof, R., Wiltshire, A., and Zaehle, S.: Global carbon budget 2013, Earth Syst. Sci. Data, 6, 235-263, doi:10.5194/essd-6-2352014, 2014.

Li, Y. and Gregory, S.: Diffusion of ions in sea water and deep sea sediments, Geochim. Cosmochim. Ac., 38, 703-714, doi:10.1016/0016-7037(74)90145-8, 1974.

Little, M., Schneider, R., Kroon, D., Bickert, T., and Wefer, G.: Rapid palaeoceanographic changes in the Benguela Upwelling System for the last 160,000 years as indicated by abundances of planktonic foraminifera, Palaeogeogr. Palaeocl., 130, 135-161, doi:10.1016/S0031-0182(96)00136-8, 1997.

Lyle, M., Mix, A., and Pisias, N.: Patterns of $\mathrm{CaCO}_{3}$ deposition in the eastern tropical Pacific Ocean for the last $150 \mathrm{kyr}$ : Evidence for a southeast Pacific depositional spike during 
marine isotope stage (MIS) 2, Paleoceanography, 17, 1013, doi:10.1029/2000PA000538, 2002.

Mackensen, A. and Bickert, T.: Stable Carbon Isotopes in Benthic Foraminifera: Proxies for Deep and Bottom water Circulation and New Production, edited by: Fischer, G. and Wefer, G., Springer, Berlin, Heidelberg, 229-254, 1999.

Mackensen, A., Grobe, H., Hubberten, H., and Kuhn, G.: Benthic foraminiferal assemblages and the $\delta^{13} \mathrm{C}$-signal in the Atlantic sector of the Southern Ocean: glacial-to-interglacial contrasts, edited by: Zahn, R., Pederson, T. F., Kaminiski, M. A., and Labeyrie, L., Springer-Verlag, Berlin, Heidelberg, 105-144, 1994.

Maeda, L., Kawahata, H., and Nohara, M.: Fluctuation of biogenic and abiogenic sedimentation on the Shatsky Rise in the western North Pacific during the late Quaternary, Mar. Geol., 189, 197214, doi:10.1016/S0025-3227(02)00405-X, 2002.

Mahowald, N., Kohfeld, K., Hansson, M., Balkanski, Y., Harrison, S., Prentice, I., Schulz, M., and Rodhe, H.: Dust sources and deposition during the last glacial maximum and current climate: A comparison of model results with paleodata from ice cores and marine sediments, J. Geophys. Res.-Atmos., 104, 15895-15916, doi:10.1029/1999JD900084, 1999.

Maier-Reimer, E.: Geochemical cycles in an ocean general circulation model - preindustrial tracer distributions, Global Biogeochem. Cy., 7, 645-677, doi:10.1029/93GB01355, 1993.

Maier-Reimer, E. and Hasselmann, K.: Transport and storage of $\mathrm{CO}_{2}$ in the ocean - an inorganic ocean-circulation carbon cycle model, Clim. Dynam., 2, 63-90, doi:10.1007/BF01054491, 1987.

Maier-Reimer, E., Mikolajewicz, U., and Hasselmann, K.: Mean circulation of the Hamburg LSG OGCM and its sensitivity to the thermohaline surface forcing, J. Phys. Oceanogr., 23, 731-757, doi:10.1175/1520-0485(1993)023<0731:MCOTHL>2.0.CO;2, 1993.

Maier-Reimer, E., Kriest, I., Segschneider, J., and Wetzel, P.: The HAMburg Ocean Carbon Cycle Model HAMOCC 5.1 - Technical Description Release 1.1, Tech. rep., Max Planck Institute for Meteorology, Hamburg, Germany, Series: Berichte zur Erdsystemforschung, no. 14, ISSN 1614-1199, 2005.

MARGO Project Members: Constraints on the magnitude and patterns of ocean cooling at the Last Glacial Maximum, Nat. Geosci., 2, 127-132, doi:10.1038/NGEO412, 2009.

Martin, B.: Statistics for physicists, Academic Press, London and New York, 209 pp., 1971.

Martin, J., Coale, K., Johnson, K., Gordon, S. F. R., Tanner, S., Hunter, C., ELROD, V., Coley, J. N. T., Barber, R., Lindley, S., Watson, A., Vanscoy, K., Law, C., Liddicoat, M., Ling, R., Stanton, T., Stockel, J., Collins, C., Anderson, A., Bidigare, R., Ondrusek, M., Latasa, M., Millero, F., Lee, K., Yao, W., Zhang, J., Friedrich, G., Sakamoto, C., Chavez, F., Buck, K., Kolber, Z., Greene, R., Falkowski, P., Chisholm, S., Hoge, F., Swift, R., Yungel, J., Turner, S., Nightingale, P., Hatton, A., Liss, P., and Tindale, N.: Testing the iron hypothesis in ecosystems of the equatorial Pacific Ocean, Nature, 371, 123-129, doi:10.1038/371123a0, 1994.

Martinson, D., Pisias, N., Hays, J., Imbrie, J., Moore, T., and Shackleton, N.: Age Dating and the orbital theory of the ice ages: development of a high-resolution 0 to 300,000-year chronos- tratigraphy, Quaternary Res., 27, 1-29, doi:10.1016/00335894(87)90046-9, 1987.

Matsumoto, K., Sarmiento, J., and Brzezinski, M.: Silicic acid leakage from the Southern Ocean: A possible explanation for glacial atmospheric $p \mathrm{CO}_{2}$, Global Biogeochem. Cy., 16, 1031, doi:10.1029/2001GB001442, 2002.

Matsumoto, K., Hashioka, T., and Yamanaka, Y.: Effect of temperature-dependent organic carbon decay on atmospheric $p \mathrm{CO}_{2}$, J. Geophys. Res.-Biogeo., 112, G02007, doi:10.1029/2006JG000187, 2007.

Matsu'ura, M. and Hirata, N.: Generalized least-squares solution to quasi-linear inverse problems with a priori information, J. Phys. Earth, 30, 451-468, doi:10.1029/RG010i001p00251, 1982.

McCave, I., Carter, L., and Hall, I.: Glacial-interglacial changes in water mass structure and flow in the SW Pacific Ocean, Quaternary Sci. Rev., 27, 1886-1908, doi:10.1016/j.quascirev.2008.07.010, 2008.

McIntyre, A.: Surface water response of the equatorial Atlantic Ocean to orbital forcing, Paleoceanography, 4, 19-55, doi:10.1029/PA004i001p00019, 1989.

McIntyre, A. and Imbrie, J.: Stable isotopes of sediment core V30-97 (specmap.011), data set, PANGAEA, doi:10.1594/PANGAEA.56356, 2000.

Mehrbach, C., Culberson, C., Hawley, J., and Pytkowic, R.: Measurement of apparent dissociation constants of carbonic acid in seawater at atmospheric pressure, Limnol. Oceanogr., 18, 897907, doi:10.4319/lo.1973.18.6.0897, 1973.

Mignot, J., Swingedouw, D., Deshayes, J., Marti, O., Talandier, C., Seferian, R., Lengaigne, M., and Madec, G.: On the evolution of the oceanic component of the IPSL climate models from CMIP3 to CMIP5: A mean state comparison, Ocean Model., 72, 167184, doi:10.1016/j.ocemod.2013.09.001, 2013.

Mix, A. C.: Carbon 13 in Pacific deep and intermediate waters, 0$370 \mathrm{KA}$ : Implications for ocean circulation and Pleistocene $\mathrm{CO}_{2}$, Paleoceanography, 6, 205-226, doi:10.1029/90PA02303, 1991.

Mollenhauer, G., Schneider, R., Müller, P., Spiess, V., and Wefer, G.: Glacial/interglacial variability in the Benguela upwelling system: Spatial distribution and budgets of organic carbon accumulation, Global Biogeochem. Cy., 16, 1134, doi:10.1029/2001GB001488, 2002.

Moy, A., Howard, W., and Gagan, M.: Late Quaternary palaeoceanography of the Circumpolar Deep Water from the South Tasman Rise, J. Quaternary Sci., 21, 763-777, doi:10.1002/jqs.1067, 2006.

Müller, P.: Carbon and nitrogen data of sediment core GeoB1711-4, data set, PANGAEA, doi:10.1594/PANGAEA.143593, 2006.

Murray, R., Knowlton, C., Leinen, M., Mix, A., and Polsky, C.: Export production and carbonate dissolution in the central equatorial Pacific Ocean over the past $1 \mathrm{Myr}$, Paleoceanography, 15, 570-592, doi:10.1029/1999PA000457, 2000.

Neftel, A., Oeschger, H., Schwander, J., Stauffer, B., and Zumbrunn, R.: Ice core sample measurements give atmospheric $\mathrm{CO}_{2}$ content during the past 40,000 yr, Nature, 295, 220-223, doi:10.1038/295220a0, 1982.

Ninkovich, D. and Shackleton, N.: Distribution, stratigraphic position and age of ash layer-L, in Panama Basin region, Earth Planet. Sc. Lett., 27, 20-34, doi:10.1016/0012-821X(75)90156-9, 1975.

O'ishi, R. and Abe-Ouchi, A.: Influence of dynamic vegetation on climate change and terrestrial carbon storage in the Last Glacial 
Maximum, Clim. Past, 9, 1571-1587, doi:10.5194/cp-9-15712013, 2013.

Oliver, K. I. C., Hoogakker, B. A. A., Crowhurst, S., Henderson, G. M., Rickaby, R. E. M., Edwards, N. R., and Elderfield, H.: A synthesis of marine sediment core $\delta^{13} \mathrm{C}$ data over the last 150000 years, Clim. Past, 6, 645-673, doi:10.5194/cp-6-6452010, 2010.

Olsen, S., Shaffer, G., and Bjerrum, C.: Ocean oxygen isotope constraints on mechanisms for millennial-scale climate variability, Paleoceanography, 20, PA1014, doi:10.1029/2004PA001063, 2005.

Orr, J.: Global Ocean Storage of Anthropogenic Carbon (GOSAC), Tech. rep., IPSL/CNRS, Saclay, France, eC Environment and Climate Programme (Contract ENV4-CT97-0495), 2002.

Parsons, T. and Takahashi, M.: Biological Oceanographic Processes, Pergamon Press, London, 166 pp., 1973.

Pierre, C., Saliege, J., Urrutiaguer, M., and Giraudeau, J.: Stable isotope record of the last 500 k.y. at Site 1087 (Southern Cape Basin), Proc. Ocean Drill. Program Sci. Results, 19, 22 pp., 2004.

Pisias, N. and Mix, A.: Spatial and temporal oceanographic variability of the eastern equatorial Pacific during the late Pleistocene: Evidence from Radiolaria microfossils, Paleoceanography, 12, 381-393, doi:10.1029/97PA00583, 1997.

Ragueneau, O., Treguer, P., Leynaert, A., Anderson, R., Brzezinski, M., DeMaster, D., Dugdale, R., Dymond, J., Fischer, G., Francois, R., Heinze, C., Maier-Reimer, E., Martin-Jézéquel, V., Nelson, D., and Quéguiner, B.: A review of the Si cycle in the modem ocean: recent progress and missing gaps in the application of biogenic opal as a paleoproductivity proxy, Global Planet. Change, 26, 317-365, doi:10.1016/S09218181(00)00052-7, 2000.

Rau, A., Rogers, J., Lutjeharms, J., Giraudeau, J., Lee-Thorp, J., M.T. Chen, and Waelbroeck, C.: A 450-kyr record of hydrological conditions on the western Agulhas Bank Slope, south of Africa, Mar. Geol., 180, 183-201, doi:10.1016/S0025-3227(01)002134, 2002.

Raven, J.: Ocean acidification due to increasing atmospheric carbon dioxide, The Royal Society (Science Policy Section), London, 60 pp., 2005.

Rea, D., Chambers, L., Chuey, J., Janacek, T., Leinen, M., and Pisias, N.: A 420,000-year record of cyclicity in oceanic and atmospheric processes from the eastern equatorial Pacific, Paleoceanography, 1, 577-586, doi:10.1029/PA001i004p00577, 1986.

Retallack, G. J.: Methane release from igneous intrusion of coal during late permian extinction events, J. Geol., 116, 1-20, doi:10.1086/524120, 2008.

Ridgwell, A.: An end to the rain ratio reign?, Geochem. Geophy. Geosy., 4, 1051, doi:10.1029/2003GC000512, 2003.

Riebesell, U., Zondervan, I., Rost, B., Tortell, P. D., Zeebe, R. E., and Morel, F. M.: Reduced calcification of marine plankton in response to increased atmospheric $\mathrm{CO}_{2}$, Nature, 407, 364-367, doi:10.1038/35030078, 2000.

Riebesell, U., Schulz, K., Bellerby, R., Botros, M., Fritsche, P., Meyerhöfer, M., Neill, C., Nondal, G., Oschlies, A., Wohlers, J., and Zöllner, E.: Enhanced biological carbon consumption in a high $\mathrm{CO}_{2}$ ocean, Nature, 450, 545-548, doi:10.1038/nature06267, 2007.

Roberts, J., Gottschalk, J., Skinner, L., Peck, V., Kender, S., Elderfield, H., Waelbroeck, C., Riveiros, N., and Hodell, D.: Evolu- tion of South Atlantic density and chemical stratification across the last deglaciation, P. Natl. Acad. Sci. USA, 113, 514-519, doi:10.1073/pnas.1511252113, 2016.

Roy, T., Bopp, L., Gehlen, M., Schneider, B., Cadule, P., Froelicher, T., Segschneider, J., Tjiputra, J., Heinze, C., and Joos, F.: Regional Impacts of Climate Change and Atmospheric $\mathrm{CO}_{2}$ on Future Ocean Carbon Uptake: A Multimodel Linear Feedback Analysis, J. Climate, 24, 2300-2318, doi:10.1175/2010JCLI3787.1, 2011.

Ruddiman, W. and Farrell, J.: Calcium carbonate content of sediment core RC13-228, data set, PANGAEA, doi:10.1594/PANGAEA.51105, 1996a.

Ruddiman, W. and Farrell, J.: Calcium carbonate content of sediment core V25-59, data set, PANGAEA, doi:10.1594/PANGAEA.51257, 1996b.

Ruddiman, W., Raymo, M., Martinson, D., Clement, B., and Backman, J.: Pleistocene evolution: northern hemisphere ice sheets and North Atlantic Ocean, Paleoceanography, 4, 353-412, doi:10.1029/PA004i004p00353, 1989.

Sarnthein, M., Erlenkeuser, H., Grafenstein, R. V., and Schröder, C.: Stable-isotope stratigraphy for the last 750,000 years: "Meteor" core 13519 from the eastern equatorial Atlantic, Meteor. Forschungsergeb., Reihe C, 38, 9-24, 1984.

Sarnthein, M., Winn, K., Jung, S., Duplessy, J., Labeyrei, L., Erlenkeuser, H., and Ganssen, G.: Changes in east Atlantic deep-water circulation over the last 30,000 years 8 time slice reconstructions, Paleoceanography, 9, 209-267, doi:10.1029/93PA03301, 1994.

Schlünz, B.: Riverine Organic Carbon Input into the Ocean in Relation to Late Quaternary Climate Change, Berichte, Fachbereich Geowissenschaften, Universität Bremen, Bremen, 116, 136 pp., 1998.

Schlünz, B., Schneider, R., Müller, P., and Wefer, G.: (Table 2) Total organic and inorganic carbon contents, and stable carbon isotope ratios of sediment core GeoB3935-2, data set, PANGAEA, doi:10.1594/PANGAEA.54943, 2000a.

Schlünz, B., Schneider, R., Müller, P., and Wefer, G.: Late Quaternary organic carbon accumulation south of Barbados: influence of the Orinoco and Amazon rivers?, Deep-Sea Res. Pt. 1, 47, 1101-1124, doi:10.1016/S0967-0637(99)00076-X, 2000b.

Schmiedl, G. and Mackensen, A.: Late quaternary paleoproductivity and deep water circulation in the eastern South Atlantic Ocean: Evidence from benthic foraminifera, Palaeogeogr. Palaeocl., 130, 43-80, doi:10.1016/S0031-0182(96)00137-X, 1997.

Schmiedl, G. and Mackensen, A.: Stable oxygen isotope records of different benthic foraminiferal species of core GeoB30041 from the western Arabian Sea, data set, PANGAEA, doi:10.1594/PANGAEA.548185, 2006.

Shackleton, N.: Carbon-13 in Uvigerina: Tropical rain forest history and the equatorial Pacific carbonate dissolution cycles, in: The fate of fossil fuel $\mathrm{CO}_{2}$ in the oceans, edited by: Andersen, N. R. and Malahoff, A., Plenum, New York, 401-428, 1977.

Shackleton, N. and Pisias, N.: Atmospheric carbon dioxide, orbital forcing, and climate, American Geophysical Union, Washington, D.C., edited by: Sundquist, E. T. and Broecker, W. S., Geophysical Monograph 32, 303-317, 1985.

Shakun, J. D., Clark, P. U., He, F., Marcott, S. A., Mix, A. C., Liu, Z., Otto-Bliesner, B., Schmittner, A., and Bard, E.: 
Global warming preceded by increasing carbon dioxide concentrations during the last deglaciation, Nature, 484, 49-54, doi:10.1038/nature10915, 2012.

Siegenthaler, U., Stocker, T. F., Monnin, E., Lüthi, D., Schwander, J., Stauffer, B., Raynaud, D., Barnola, J.-M., Fischer, H., Masson-Delmotte, V., and Jouzel, J.: Stable carbon cycle-climate relationship during the Late Pleistocene., Science, 310, 13131317, doi:10.1126/science.1120130, 2005.

Sigman, D. and Boyle, E.: Glacial/interglacial variations in atmospheric carbon dioxide, Nature, 407, 859-69, doi:10.1038/35038000, 2000.

Skinner, L., Shackleton, N., and Elderfield, H.: Millennial-scale variability of deep-water temperature and delta $\delta^{18} \mathrm{O}_{\mathrm{dw}}$ indicating deep-water source variations in the Northeast Atlantic, 0-34 cal. ka BP, Geochem. Geophy. Geosy., 4, 1098, doi:10.1029/2003GC000585, 2003.

Smith, C. and Rabouille, C.: What controls the mixed-layer depth in deep-sea sediments? The importance of POC flux, Limnol. Oceanogr., 47, 418-426, doi:10.4319/lo.2002.47.2.0418, 2002.

Stute, M., Forster, M., Frischkorn, H., Serejo, A., Clark, J., Schlosser, P., Broecker, W., and Bonani, G.: Cooling of tropical Brazil $\left(5^{\circ} \mathrm{C}\right)$ during the last glacial maximum, Science, 269 , 379-383, doi:10.1126/science.269.5222.379, 1995.

Svensen, H., Planke, S., Polozov, A., Schmidbauer, N., Corfu, F., Podladchikov, Y., and Jamtveit, B.: Siberian gas venting and the end-Permian environmental crisis, Earth Planet. Sc. Lett., 277, 490-500, doi:10.1016/j.eps1.2008.11.015, 2009.

Thomson, J., Nixon, S., Summerhayes, C., Schönfeld, J., Zahn, R., and Grootes, P.: Implications for sedimentation changes on the Iberian margin over the last two glacial/interglacial transitions from $\left({ }^{230} \mathrm{Th}_{\text {excess }}\right)_{0}$ systematics, Earth Planet. Sc. Lett., 165, 255-270, doi:10.1016/S0012-821X(98)00265-9, 1999.

Thomson, J., Nixon, S., Summerhayes, C., Rohling, E., Schönfeld, J., Zahn, R., Grootes, P., Abrantes, F., Gaspar, L., and Vaqueiro, S.: Enhanced productivity on the Iberian margin during glacial/interglacial transitions revealed by barium and diatoms, J. Geol. Soc., 157, 667-677, doi:10.1144/jgs.157.3.667, 2000.

Toggweiler, J., Russell, J., and Carson, S.: Midlatitude westerlies, atmospheric $\mathrm{CO} 2$, and climate change during the ice ages, Paleoceanography, 21, doi:10.1029/2005PA001154, 2006.

Turley, C. and Mackie, P.: Bacterial and cyanobacterial flux to the deep NE Atlantic on sedimenting particles, Deep-Sea Res. Pt. 1, 42, 1453-1474, doi:10.1016/0967-0637(95)00056-C, 1995.

Ullman, W. and Aller, R.: Diffusion coefficients in nearshore marine sediments, Limnol. Oceanogr., 27, 552-556, doi:10.4319/lo.1982.27.3.0552, 1982.

Van Cappellen, P., Dixit, S., and van Beusekom, J.: Biogenic silica dissolution in the oceans: Reconciling experimental and field-based dissolution rates, Global Biogeochem. Cy., 16, 1075, doi:10.1029/2001GB001431, 2002.

Verardo, D. and McIntyre, A.: Production and destruction: Control of biogenous sedimentation in the tropical Atlantic 0-300,000 Years B.P., Paleoceanography, 9, 63-86, doi:10.1029/93PA02901, 1994.
Watson, A. and Garabato, A.: The role of Southern Ocean mixing and upwelling in glacial-interglacial atmospheric $\mathrm{CO}_{2}$ change, Tellus B, 58, 73-87, doi:10.1111/j.1600-0889.2005.00167.x, 2006.

Watson, A., Vallis, G., and Nikurashin, M.: Southern Ocean buoyancy forcing of ocean ventilation and glacial atmospheric $\mathrm{CO}_{2}$, Nat. Geosci., 8, 861-864, doi:10.1038/NGEO2538, 2015.

Weiss, R.: The solubility of nitrogen, oxygen and argon in water and seawater, Deep-Sea Res., 17, 721-735, doi:10.1016/00117471(70)90037-9, 1970.

Weiss, R.: Carbon dioxide in water and seawater: The solubility of a non-ideal gas, Mar. Chem., 2, 203-215, 1974.

Weyhenmeyer, C., Burns, S., Waber, H., Aeschbach-Hertig, W., Kipfer, R., Loosli, H., and Matter, A.: Cool glacial temperatures and changes in moisture source recorded in Oman groundwaters, Science, 287, 842-845, doi:10.1126/science.287.5454.842, 2000.

Wiggins, R.: The general linear inverse problem: Implication of surface waves and free oscillations for Earth structure, Rev. Geophys., 10, 251-285, doi:10.1029/RG010i001p00251, 1972.

Winguth, A., Archer, D., Duplessy, J., Maier-Reimer, E., and Mikolajewicz, U.: Sensitivity of paleonutrient tracer distributions and deep-sea circulation to glacial boundary conditions, Paleoceanography, 14, 304-323, doi:10.1029/1999PA900002, 1999.

Wunsch, C.: Tracer inverse problems, Kluwer Academic Publishers, Dordrecht, Anderson, D. L. T. and Willebrand, J., 1-77, 1989.

Yu, J., Anderson, R., and Rohling, E.: Deep Ocean Carbonate Chemistry and Glacial-Interglacial Atmospheric $\mathrm{CO}_{2}$ Changes, Oceanography, 27, 16-25, doi:10.5670/oceanog.2014.04, 2014.

Zabel, M., Bickert, T., and Dittert, L.: Significance of the sedimentary $\mathrm{Al}$ : Ti ratio as an indicator for variations in the circulation patterns of the equatorial North Atlantic, Paleoceanography, 14, 789-799, doi:10.1029/1999PA900027, 1999.

Zachos, J. C., Röhl, U., Schellenberg, S. A., Sluijs, A., Hodell, D. A., Kelly, D. C., Thomas, E., Nicolo, M., Raffi, I., Lourens, L. J., McCarren, H., and Kroon, D.: Rapid acidification of the ocean during the Paleocene-Eocene thermal maximum, Science, 308, 1611-1615, doi:10.1126/science.1109004, 2005.

Zahn, R., Wynn, K., and Sarnthein, M.: Benthic foraminiferal $\delta^{13} \mathrm{C}$ and accumulation rates of organic carbon: Uvigerina Peregrina group and Cibicidoides Wuellerstorfi, Paleoceanography, 1, 2742, doi:10.1029/PA001i001p00027, 1986.

Zahn, R., Schönfeld, J., Kudrass, H., Park, M., H Erlenkeuser, H., and Grootes, P.: Thermohaline instability in the North Atlantic during meltwater events: Stable isotope and ice-rafted detritus records from core SO75-26KL, Portuguese margin, Paleoceanography, 12, 696-710, doi:10.1029/97PA00581, 1997.

Zeng, N.: Glacial-interglacial atmospheric $\mathrm{CO}_{2}$ change - The glacial burial hypothesis, Adv. Atmos. Sci., 20, 677-693, doi:10.1007/BF02915395, 2003.

Zondervan, I., Zeebe, R., Rost, B., and Riebesell, U.: Decreasing marine biogenic calcification: A negative feedback on rising atmospheric $p \mathrm{CO}_{2}$, Global Biogeochem. Cy., 15, 507-516, doi:10.1029/2000GB001321, 2001. 